iktisad jebupor

\title{
A Study on The Determination of The Association Between Consumers' Price Perceptions and Their Demographic Characteristics
}

\author{
Tüketicilerin Fiyat Algılamaları ile Demografik Özellikleri Arasındaki \\ İlişkinin Belirlenmesi Üzerine Bir Araştırma
}

\begin{abstract}
$\underline{\text { Article Info }}$

Paper Type: Research Paper

Received:

15.12.2020

Accepted:

28.08.2021

(C) 2021 JEBUPOR All rights reserved.

Price perception, which influences buying behaviour and product selection, is an important tool in companies' strategies to be developed about the price of the product and in their success. The main purpose of this study is to find out the relationship between consumers' occupations and the dimensions which constitute their price perception. For this purpose, a questionnaire was given to 579 consumers who were from 10 different occupations. In the analysis, independent samples test was used to compare the consumers in terms of gender variable; while one-way ANOVA was used to compare the consumers in terms of the variables of monthly income, age, educational status and occupation. According to the results obtained, there is a significant relationship between consumers' demographic characteristics and occupations and the dimensions of price perception. The present study is significant in terms of being the first and the most recent study in terms of the scope of the participants' occupations, examination of the relationship between the dimensions creating price perception and the number of participants. In parallel with the results obtained in the study, various suggestions were developed to contribute to companies the target market of which is Turkey and to the related literature.
\end{abstract}

Makale Bilgileri

Keywords: Price perception, occupation, demographic characteristics, consumer behaviour.

Makale Türü: Araştırma

Makalesi

Geliș Tarihi:

15.12.2020

Kabul Tarihi: 28.08.2021

(C) 2021 IKTISAD Tüm hakları saklıdır.

\section{(i) (\$)}

Öz

Satın alma davranışını ve ürün seçimini etkileyen fiyat algısı; işletmelerin ürünlerinin fiyatına ilişkin geliştirecekleri stratejilerde ve başarllarında önemli bir araç durumundadır. Bu çalışmanın temel amacı, tüketicilerin meslekleri ile fiyat algısını oluşturan boyutlar arasındaki ilişkinin tespit edilmesidir. Bu amaçla, 10 farklı meslek grubundan oluşan 579 tüketiciye anket uygulanmıştır. Araştırma analizinde, tüketicileri cinsiyet değişkenine göre karşılaştırmak için bă̆ımsız örneklem $t$ testi; aylık gelir, yaş, eğitim durumu ve meslek değişkenlerine göre karşılaştırmak için ise tek yönlü varyans analizi uygulanmıştır. Elde edilen sonuçlara göre, tüketicilerin demografik özellikleri ve meslekleri ile fiyat algılarını oluşturan boyutlar arasında anlamlı bir farklılık bulunmaktadır. Bu çalışma, katılımcıların oluşturduğu meslek gruplarının kapsamı, fiyat algısını oluşturan boyutlar ile farklılıkların incelenmesi ve katılımcı sayısı açısından Türkiye'de yapılmış ilk ve en güncel çalışma olması açısından önem taşımaktadır. Araştırmada elde edilen sonuçlar doğrultusunda, hedef pazarı Türkiye olan işletmelere ve ilgili literatüre katkı sağlamak amacıyla çeşitli öneriler geliştirilmiştir.

Anahtar Kelimeler: Fiyat algısı, meslek, demografik özellikler, tüketici davranışı.

To Cite/ Atıf (APA): Özden, A.T. (2021). A study on the determination of the association between consumers' price perceptions and their demographic characteristics. Journal of Economics Business and Political Researches, 6(16), 453-479

* ORCID Öğr. Gör. Dr., Ondokuz Mayıs Üniversitesi, Samsun Meslek Yüksekokulu, Pazarlama ve Reklamcıllk Bölümü, aybike.ozden@omu.edu.tr 


\section{INTRODUCTION}

In its most basic form, price can be considered as the source that consumers have to give up while buying products. Companies need to convince consumers that the resources they pay for their products are dispensable. As a matter of fact, price, which is an important element of the marketing mix, plays a significant role in the formation of the image and value of the product (Geçti and Zengin, 2012: 30; Yaraş, 2008: 282), customer loyalty (Hartono et al., 2018) or satisfaction (Ene and Özkaya, 2013: 451). At this point, consumers' price perceptions gain importance. Consumers' price perception is a subjective process and shows differences.

In various studies, it has been found that consumers' occupations are effective in their brand choice (Arslan, 2003), choices of tourism services (Çakıc1, 1999), ethnocentric tendencies (Armağan and Gürsoy, 2011), bread consumption habits (Aydın and Y1ldız, 2011), consumption of halal products (Mutsikiwa and Basera, 2012), and preferring known brands while choosing furniture (Çabuk et al., 2012). Therefore, consumers' occupation may affect their buying behaviors. It can be said that consumers' gender, age, level of education and level of income have an influence on their price perception (McGowan and Sternquist, 1998; Munnukka, 2008; Steenhuis et al., 2011; Zhou and Nakamoto, 2001). Especially the factor of occupation can be assessed as an indicator of consumers' levels of education and income and it is thought to have an influence on price perception. The aim of this study is to examine the relationship between consumers' demographic characteristics and occupations and the dimensions which form their price perception. Consumer price perception consists of the dimensions of prestige sensitivity, price consciousness, sale proneness, price-quality relationship, value consciousness and coupon proneness (Lichtenstein et al., 1993: 235-236).

Companies want consumers' buying decision process to be finalized as soon as possible (Rao and Monroe, 1988: 255). For this reason, it is thought that companies should find out which factors consumer' price perceptions are affected from so that they can influence consumers' buying decisions. Consumers' price perceptions are also influenced by intercultural differences (Jin and Sternquist, 2003; Meng, 2011; Meng and Nasco, 2009; Watchravesringkan et al., 2008; Zhou and Nakamoto, 2001). For this reason, it is important to find out the factors which influence price perceptions of consumers. Indeed, the results obtained include data which will determine the pricing policies of companies in Turkey and enable them to develop strategies.

In the present study, the main purpose was to examine the relationship between occupations and price perception dimensions of consumers who are an important factor of market segmentation. The two hypotheses of the research are as follows: "There is a significant relationship between consumers" occupations and their prices perceptions." and "There is a significant relationship between consumers' demographic characteristics and their prices perceptions".

\section{LITERATURE REVIEW}

\subsection{Price Perception}

Perception is one of the most important internal and psychological factors which influence consumers' buying behaviours (Ramya and Mohamed Ali, 2016: 77). Another factor which influences consumer buying is price (Geçti and Zengin, 2012: 29). In its most basic sense, price can be defined as the money that consumers pay to buy a product. Product price is evaluated in two as actual price and perceived price (Jacoby and Olson, 1977: 74). Actual price refers to the price paid by the consumer to the product (Küçükergin and Dedeoğlu, 2014: 102). Perceived price is consumers' perspectives on the price they pay for the product they buy (Bei and Chaio, 2006: 129). Therefore, price perceptions of consumers may vary according to their perspectives. Consumers perceive every kind of data about the outside world by passing them through their subjective filters and they also experience a similar perception process about the price of a product. For this reason, in addition to 
being the value of a product, price also carries various meanings related with the quality, prestige, identity or status of the product in terms of the consumer.

Price perception can be defined as consumers' views about the money paid for the product they buy (Bei and Chiao, 2006: 129). According to another definition, price perception is the way consumers evaluate the advantages they receive for the product they buy (Küçükergin and Dedeoğlu, 2014: 102). Evaluation process is a subjective process. In this sense, it is thought that price is not a uni-dimensional concept and that it contains multiple dimensions in terms of the meanings it expresses for the consumer. These dimensions form the negative or positive role of the price. The negative role of price perception means consumers' having a negative perception of the product when the price is high. The positive role of price means the price of a product is a positive sign for consumers in terms of reasons such as being indicator of quality or prestige. Lichtenstein et al. (1993: 325) state that consumer's' price perception consists of seven dimensions. These dimensions and the explanations about the negative/positive roles of the dimensions are as follows:

- Price Mavenism: It can be defined as consumers' knowing where to buy the lowest price products and being willing to give reference to other consumers about this (Lichtenstein et al., 1993: 235; Jin and Sternquist, 2003: 649). In price mavenism, consumers do not only collect information about the price, but also give ideas about their consumption preferences and share their information about the best price (Sternquist et al., 2004: 88). Price mavenism constitutes the negative role of price perception. However, Byun and Sternquist (2010: 281) stated that price perception has both positive and negative role. According to these researchers, price mavenism constitutes the positive role of price perception in terms of consumers' both being a source of information and taking pleasure from sharing their information. In this context, it can be said that price mavenism is a cultural and social phenomenon (Byun and Sternquist, 2010: 279). Culturally, sharing information about the price of product can vary from culture to culture. Socially, while some consumers collect information only for themselves, some others can prefer to share with other consumers (Dickson and Sawyer, 1990: 43).

- Prestige Sensitivity: It can be said that values such as difference, conspicuousness, status, sociability, respectability or quality are the elements that provide prestige. Consumers, who associate prestige with the price of the product, have a much higher tendency to buy the products which they think give them prestige (Watchravesringkan et al., 2008: 761). Thus, prestige sensitivity constitutes the positive role of price perception. These consumers also tend to perceive price as an indicator of quality (Lichtenstein et al., 1993: 236). Consumers with prestige sensitivity are interested in the message they want to convey to other consumers with the high price product (Meng and Nasco, 2009: 508). This is an indicator that prestige has a social element such as image, status or richness, which are symbolic needs (Brucks et al., 2000: 361). For this reason, it can be said that consumers with prestige sensitivity tend to buy products which are visible and which will be realized by others (Moore et al., 2003:270). In addition, these consumers do not prefer shops which sell cheap products (Moore and Carpenter, 2006: 269).

- Price Consciousness: Price consciousness can be defined as consumers' being focused on buying products with low price (Lichtenstein et al., 1993: 235; Jin and Sternquist, 2003: 650). For this reason, it constitutes negative role of price perception. Thus, it can be said that consumers with a price consciousness have a low tendency to buy products with high price and the price range they can pay for the product they intend to buy is narrow (Munnukka, 2008: 189). At the same time, there is a negative association between price-quality consciousness and price consciousness for these consumers (Lichtenstein et al., 1993: 235). Thus, for price conscious consumers, low price does not mean low quality.

- Sale Proneness: Buying behaviours of consumers who are prone to sale are influenced positively (Lichtenstein et al., 1993: 235). Thus, sale proneness constitutes negative role of price perception. Consumers who are sale prone make researches to reach the lowest price product, pay attention to special offers and change brands frequently. It can be said that these consumers prefer 
to make use of sale while purchasing. Indeed, instead of discount conveniences such as coupon or refund, consumers perceive the price of a product lower when they make use of discount (Folkes and Wheat, 1995: 317). However, it can also be possible for brands which make frequent discounts to be perceived as low quality and the real price to be evaluated as high when the discount is over. Big discounts or frequent discounts can change consumers' reference price perceptions and have a negative effect on their buying products.

- Price-quality Relationship: Price-quality relationship can be described as the subjective expectation of consumers about the price and quality compatibility of a product (Chang et al., 2015: 73). Price-quality relationship constitutes positive role of price perception. For consumers who build a price-quality relationship, the price of a product is addressed as the indicator of quality. For this reason, consumers can tend to find products with high price as quality products (Casidy, 2012; McGowan and Sternquist, 1998; Olson, 1977; Rao and Monroe, 1989). However, in parallel with the information consumers have besides the price of the product, their perceptions about price-quality relationship can change (Peter and Olson, 2010: 446). In case of having insufficient information about the product, price-quality relationship of consumers can show variations. In case of consumers' having insufficient information about the product, the price of the product can have a positive influence on quality perception (Dodds et al., 1991: 307). In other words, when consumers have more experience and information about the product, they show a low tendency to build price-product relationship (Jin and Sternquist, 2003; Meng, 2011).

- Value Consciousness: Value consciousness can be described as the sensitivity consumers show to the price of a product depending on its quality. Value consciousness constitutes negative role of price perception. Thus, consumers with a high value consciousness consider the product they buy as loss or gain according to the quality of the product they buy. Consumers with high value consciousness examine and compare the prices of different brands and want to get the return of the money they pay in the best way (Sharma, 2011: 290). This comparison process enables consumers to get information about the product. In case of consumers' having insufficient information about the product, the price of the product has a negative influence of the perceived value (Dodds et al., 1991: 316). At the same time, people have a sensitivity of the price paid for the product in return of the quality received (Lichtenstein et al., 1993: 234). For this reason, it can be said that consumers with value consciousness care about the relationship between the money they pay for the product and the quality they get (Jin and Sternquist, 2003; Meng and Nasco, 2009; Varki and Colgate, 2001).

- Coupon Proneness: With coupons, consumers think that they get a discount offer about the product they want to buy. Coupons constitute the practices that offer discount after consumers' purchases or extra opportunities in shopping. Consumers with coupon proneness think that when they use coupon, the value of the product they buy is higher than the money they pay. For this reason, they perceive the price of the product lower (Folkes and Wheat, 1995: 317). Thus, coupon proneness constitutes the negative role of price perception and has positive influence on buying (Lichtenstein et al., 1993: 235). Discount with coupon, which goes back to 1929s in Turkey, and practices such as gifts or draw were made through newspapers (Özdemir, 2018: 135). This process continued until the beginning of $90 \mathrm{~s}$. However, today coupon does not have a widespread use in Turkey (Yaraş, 2008: 284). For this reason, in the scale used for this study, the items for coupon proneness are not included. The Price Perception scale used in the study was developed by Lichtenstein, Ridgway and Netemeyer in 1993 and it is a scale that can be used in different cultures (Meng and Nasco, 2009: 508).

It is thought that the factor of occupation, which is one of the factors influencing consumer behaviour, influences price perception of consumers. Fettahlığlu et al. (2019: 5938) found that private sector employees have higher price-quality perception when compared with civil servants, housewives, tradesmen and students. Topuz and Çambaş 1 (2014) stated that consumers have different sale proneness and price consciousness depending on their occupations. For example, caretakers have higher sale proneness when compared with administrative staff and less price consciousness when 
compared with waiters and sales representatives (Topuz and Çambaşı, 2014: 324). In this context, the following hypotheses were developed:

H1.There is a significant difference between consumers' occupations and their prices perceptions.

H1a. There is a significant difference between consumers' occupations and value consciousness, which is one of the dimensions of price perception.

H1b. There is a significant difference between consumers' occupations and price consciousness, which is one of the dimensions of price perception.

H1c. There is a significant difference between consumers' occupations and sale proneness, which is one of the dimensions of price perception.

H1d. There is a significant difference between consumers' occupations and price mavenism, which is one of the dimensions of price perception.

H1e. There is a significant difference between consumers' occupations and price-quality relationship, which is one of the dimensions of price perception.

H1f. There is a significant difference between consumers' occupations and prestige sensitivity, which is one of the dimensions of price perception.

\subsection{Consumer Behaviour and Demographic Characteristics}

Consumer behavior is influenced by various factors such as age, lifestyle, economic conditions, occupation, character and health (Durmaz et al., 2011: 118). The relationship of these factors with consumer behavior is important in determining the strategies of businesses in target markets. This study discusses the relationship of gender, age, income level, education level and occupation factors of consumers with their price perceptions. These factors can be summarized as follows:

- Gender: The wants of women and men may differ. For example, it can be seen that female consumers have higher hedonic consumption tendencies (Arnold and Reynolds, 2003: 81) and they are more influenced by their past experiences when compared with men (Ağaç et al., 2018: 66).

- Age: Consumers' ages influence their buying behaviors (Durmaz et al., 2011: 119). The wants and needs of a young consumer and an old consumer may differ. For example, young consumers use the products they buy to define their identities (Solomon, 1994: 503). Old consumers may show different buying behaviors due to health problems. For example, organic fruit and vegetables are mostly preferred by old consumers (Saba and Messina, 2003: 645).

- Income level: Consumers have a purchasing power in line with their income level. For this reason, income level may influence consumers' buying behaviors. For example, a consumer with low level of income may show the tendency to choose a product which does not have a brand or which is cheaper. Consumers with low level of income perceive supermarket brand cleaning products as higher quality than consumers with high income (Orel, 2004: 171).

- Education level: Different education levels of consumers may cause differences in wants and needs. For example, it can be seen that consumers prefer green marketing products more as their education level increases (Çabuk et al., 2008: 91).

- Occupation: Consumers may show different buying behaviors due to their occupational needs. Consumers' income, working time, likes or ways of spending leisure time also change due to their occupation. While a consumer who is a worker may prefer to buy the cheapest product, a senior executive may prefer not to change the brand s/he buys, regardless of its price. For example, it can be seen that consumers' brand loyalty differs according to their profession (Gürbüz and Doğan, 2013: 239). 
It can be said that businesses use these demographic characteristics frequently while determining their target markets. As a matter of fact, these demographic characteristics affect consumption habits as well as consumers' lifestyles, likes or social environment.

It is thought that there is a relationship between consumers' demographic characteristics and their price perceptions. Indeed, Munnukka (2008: 193) stated that consumers' age and gender influenced their price perception. McGowan and Sternquist (1998: 62) stated that socially conscious and young consumers had higher prestige sensitivity. Similarly, Zhou and Nakamoto (2001: 161) stated that young consumers are consumers with value consciousness. Akman (2004) found that female consumers compared prices more when compared with male consumers and this comparison decreased as the level of education increased. Bozbay and Akturan (2017: 87) stated that female consumers had a higher perception than male consumers in the dimensions of price mavenism and sale proneness. Steenhuis et al. (2011:2220) found that consumers with low income had higher value consciousness and price consciousness dimensions when compared with consumers with high income. In this context, the following hypotheses were developed:

H2. There is a significant difference between consumers' demographic characteristics and their prices perceptions.

H2a. There is a significant difference between consumers' genders and their prices perceptions.

$\mathrm{H} 2 \mathrm{~b}$. There is a significant difference between consumers' ages and their prices perceptions.

H2c. There is a significant difference between consumers' education levels and their prices perceptions.

H2d. There is a significant difference between consumers' income levels and their prices perceptions.

\section{RESEARCH METHODOLOGY}

The questionnaire form, which was used to collect data, consists of 2 parts. The first part includes the items of Price Perception Scale developed by Lichtenstein et al. (1993) in order to measure the price perceptions of consumers. Ünsalan and Bayraktar (2017) found that Price Perception Scale is valid and reliable for Turkish consumers. Turkish form used by Ünsalan and Bayraktar (2017) was used in this study. The scale was also used in the studies conducted by Bozbay and Akturan (2017), Geçti (2012), Dülgeroğlu (2017), Kurtuluş and Okumuş (2010), Topuz and Çambaşı (2014) and Yaraş (2008) in Turkey. This scale has dimensions of price mavenism, prestige sensitivity, price consciousness, sale proneness, price-quality relationship, value consciousness and coupon proneness. Coupon is a practice which is not widely used in European and Asian countries and it is not evaluated in many studies (Meng, 2011; Meng and Nasco, 2009; Moore et al., 2003; Sternquist et al., 2004; Watchravesringkan et al., 2008; Ünsalan and Bayraktar, 2017; Yaraş, 2008). Turkey has a geopolitical location that combines the continents of Asia and Europe. Thus, coupon proneness items were not included in the present study. The 37 variables in the scale were asked with 5 Likert-type scale. In the Likert scale, the assessment is in the form of (1) Totally disagree, (2) Disagree, (3) No idea, (4) Agree, (5) Totally agree. The second part of the questionnaire form includes information about the participants such as their genders, ages, occupations, education levels and income levels. The occupations in the study were chosen among groups used in many studies (Geçti and Zengin, 2012; Kurtuluş and Okumuş, 2006; Yaraş, 2008) and among groups which form the most widespread occupations in Turkey.

The questionnaires were applied in three big cities of Turkey, the provinces of Ankara, Samsun and İstanbul, between September 2 and January 16, 2020. These cities are the most developed and most cosmopolitan cities of the regions they are in. At the same time, Samsun was chosen because the researcher is working in Samsun. The participants consist of consumers older than the age of 18. 
605 consumers were reached with easy sampling method. Easy sampling is a non-random sampling method in which the sample to be chosen from the population is determined by the researcher (Haşıloğlu et al., 2015). This method is the most commonly used, easy to access and inexpensive method (Yağar and Dökme, 2018). 26 questionnaires which were not filled in correctly were eliminated and 579 questionnaires were evaluated. The questionnaires were conducted face-to-face with consumers who were working or who were members of trade associations, schools, universities, chambers of commerce, nongovernmental organizations, hospitals and municipalities and participants in academic congresses. The questionnaires were transferred to digital medium, sent to professional platforms formed in various social media and consumers filled in the questionnaires.

\subsection{Aim and Significance of the Study}

Price perception is an important indicator of consumer behaviour (Zeithaml, 1988: 2). In the present study, the main purpose was to examine the relationship between occupations and price perception dimensions of consumers who are an important factor of market segmentation. Pricing strategies implemented by businesses can be perceived differently in consumers of different social classes due to different price sensitivity (Yan et al., 2017: 463). For this reason, businesses may develop different pricing strategies for different occupations. For example, telephone operators may apply price lists for different occupations. The research can both shed a light on the future studies of practitioners and also help companies to determine their pricing policies in the market more specifically. In addition, the present study is important in terms of the scope of the occupations of the participants and the fact that the relationship between the number of participants, the dimensions constituting price perception and occupation groups is examined one by one. Unlike other studies, the present study examined the relationships between 10 different specific and comprehensive occupation groups and price perception dimensions one by one. The occupation groups covered were: Officer, student, housewife, manager, worker, teacher, doctor, engineer, academician, tradesmen. For example, Topuz and Çambaş1 (2014) carried out a study on price perceptions of minimum wage consumers in mobile phone sector. Therefore, this study aims to obtain more comprehensive results because of the diversity of selected occupation groups and because it was conducted without choosing any sector.

\subsection{Model of the Study}

Demographic characteristics influence price perceptions of consumers (Bozbay and Akturan, 2017: 87; Fettahlığlu et al., 2019: 5930). Therefore, businesses carry out market segmentation according to demographic characteristics (Kavak and Aksöz, 2003: 231). Therefore, demographic characteristics are important in knowing consumers closely and determining target market. Occupation of consumers is an important factor determining their lifestyle. Consumers may differ from other occupation groups with features such as working hours, working conditions, income, saving tendencies, spending habits and education received. In fact, consumers in similar social classes show similar buying behaviors (Karabulut, 1981: 74). For this reason, it is thought that examining the relationship between occupational groups and price perception is important in determining the target markets and pricing strategies of businesses. The research model developed in this context is as in Figure 1. 


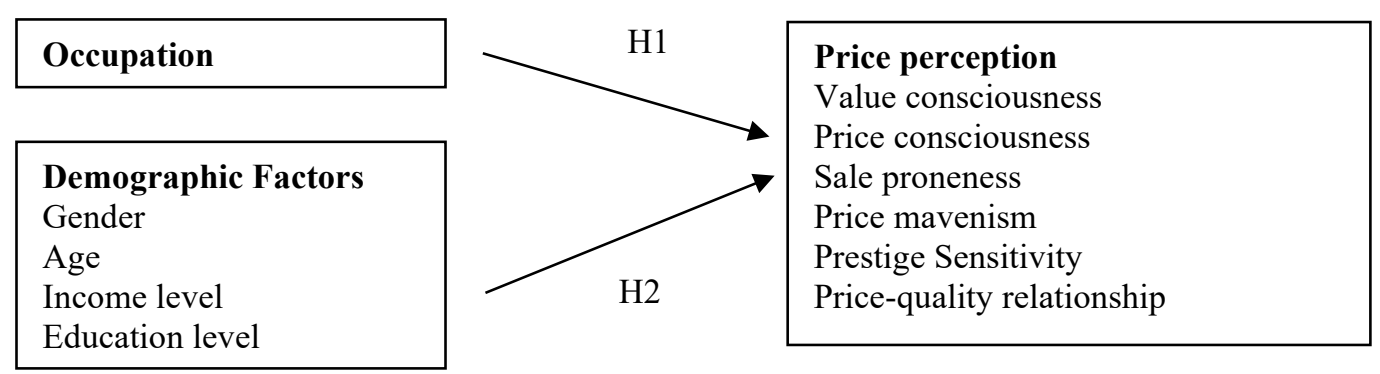

Figure 1: Research Model

\subsection{Demographic Data}

Demographic data of the participants are shown in Table 1.

Table 1: Demographic Variables

\begin{tabular}{|c|c|c|c|}
\hline & & $\mathrm{n}$ & $\%$ \\
\hline \multirow{2}{*}{ 1. Gender: } & Female & 312 & 53.9 \\
\hline & Male & 267 & 46.1 \\
\hline \multirow{5}{*}{ 2. How much is your monthly individual net income? } & Less than $2021 \mathrm{TL}$ & 113 & 19.5 \\
\hline & $2021-5000 \mathrm{TL}$ & 151 & 26.1 \\
\hline & $5001-8000 \mathrm{TL}$ & 168 & 29.0 \\
\hline & $8001-11000 \mathrm{TL}$ & 110 & 19.0 \\
\hline & More than $11000 \mathrm{TL}$ & 37 & 6.4 \\
\hline \multirow{5}{*}{ 3. Age } & $18-25$ & 132 & 22.8 \\
\hline & $26-35$ & 131 & 22.6 \\
\hline & $36-45$ & 138 & 23.8 \\
\hline & $46-55$ & 125 & 21.6 \\
\hline & 56 and older & 53 & 9.2 \\
\hline \multirow{6}{*}{ 4. Education level: } & Primary & 18 & 3.1 \\
\hline & High school & 92 & 15.9 \\
\hline & Associate & 119 & 20.6 \\
\hline & Undergraduate & 219 & 37.8 \\
\hline & Master & 82 & 14.2 \\
\hline & Doctorate & 49 & 8.5 \\
\hline \multirow{10}{*}{ 5. Occupation: } & Officer & 56 & 9.7 \\
\hline & Student & 94 & 16.2 \\
\hline & Housewife & 53 & 9.2 \\
\hline & Manager & 51 & 8.8 \\
\hline & Worker & 55 & 9.5 \\
\hline & Teacher & 53 & 9.2 \\
\hline & Doctor & 56 & 9.7 \\
\hline & Engineer & 51 & 8.8 \\
\hline & Academician & 56 & 9.7 \\
\hline & Tradesman & 54 & 9.3 \\
\hline
\end{tabular}

Of the participants, $53.9 \%$ were female; $29.0 \%$ had a monthly individual net income of 5001$8000 \mathrm{TL} ; 23.8 \%$ were between 36 and 45 years of age; $37.8 \%$ were undergraduates and $16.2 \%$ were students.

Descriptive statistics of the expressions in the study are shown in Table 2. 
Table 2: Descriptive statistics of the expressions

\begin{tabular}{|c|c|c|c|c|c|c|c|c|c|c|c|c|}
\hline & \multicolumn{2}{|c|}{ Totally disagree } & \multicolumn{2}{|c|}{ Disagree } & \multicolumn{2}{|c|}{ No idea } & \multicolumn{2}{|c|}{ Agree } & \multicolumn{2}{|c|}{ Totally agree } & \multirow{2}{*}{ Mean } & \multirow{2}{*}{ sd } \\
\hline & $\mathrm{n}$ & $\%$ & $\mathrm{n}$ & $\%$ & $\mathrm{n}$ & $\%$ & $\mathrm{n}$ & $\%$ & $\mathrm{n}$ & $\%$ & & \\
\hline $\begin{array}{l}\text { 1My friends think of me as a } \\
\text { good source of price } \\
\text { information. }\end{array}$ & 255 & 44.0 & 93 & 16.1 & 63 & 10.9 & 119 & 20.6 & 49 & 8.5 & 2.33 & 1.42 \\
\hline $\begin{array}{l}2 \text { I'm considered somewhat of } \\
\text { an expert when it comes to } \\
\text { knowing the prices of products }\end{array}$ & 297 & 51.3 & 102 & 17.6 & 61 & 10.5 & 77 & 13.3 & 42 & 7.3 & 2.08 & 1.34 \\
\hline $\begin{array}{l}3 \text { People ask me for information } \\
\text { about prices for different types } \\
\text { of products. }\end{array}$ & 234 & 40.4 & 139 & 24.0 & 58 & 10.0 & 97 & 16.8 & 51 & 8.8 & 2.30 & 1.37 \\
\hline $\begin{array}{l}4 \text { I like helping people by } \\
\text { providing them with price in- } \\
\text { formation about many types of } \\
\text { products. }\end{array}$ & 259 & 44.7 & 112 & 19.3 & 42 & 7.3 & 88 & 15.2 & 78 & 13.5 & 2.33 & 1.49 \\
\hline $\begin{array}{l}5 \text { For many kinds of products, I } \\
\text { would be better able than most } \\
\text { people to tell someone where to } \\
\text { shop to get the best buy. }\end{array}$ & 270 & 46.6 & 103 & 17.8 & 60 & 10.4 & 85 & 14.7 & 61 & 10.5 & 2.25 & 1.43 \\
\hline $\begin{array}{l}6 \text { I enjoy telling people how } \\
\text { much they might expect to pay } \\
\text { for different kinds of products. }\end{array}$ & 254 & 43.9 & 93 & 16.1 & 42 & 7.3 & 108 & 18.7 & 82 & 14.2 & 2.43 & 1.53 \\
\hline $\begin{array}{l}7 \text { I buy expensive brand of a } \\
\text { product just because I know } \\
\text { other people will notice }\end{array}$ & 320 & 55.3 & 105 & 18.1 & 28 & 4.8 & 73 & 12.6 & 53 & 9.2 & 2.02 & 1.39 \\
\hline $\begin{array}{l}8 \text { Buying the most expensive } \\
\text { brand of a product makes me } \\
\text { feel classy. }\end{array}$ & 291 & 50.3 & 97 & 16.8 & 24 & 4.1 & 88 & 15.2 & 79 & 13.6 & 2.25 & 1.52 \\
\hline $\begin{array}{l}9 \text { I enjoy the prestige of buying } \\
\text { a high priced brand }\end{array}$ & 239 & 41.3 & 112 & 19.3 & 48 & 8.3 & 96 & 16.6 & 84 & 14.5 & 2.44 & 1.51 \\
\hline $\begin{array}{l}10 \text { Even for a relatively } \\
\text { inexpensive product, I think that } \\
\text { buying a costly brand is } \\
\text { impressive }\end{array}$ & 306 & 52.8 & 92 & 15.9 & 43 & 7.4 & 77 & 13.3 & 61 & 10.5 & 2.13 & 1.44 \\
\hline $\begin{array}{l}11 \text { Buying a high priced version } \\
\text { of a product gives positive } \\
\text { message to people. }\end{array}$ & 254 & 43.9 & 107 & 18.5 & 53 & 9.2 & 85 & 14.7 & 80 & 13.8 & 2.36 & 1.49 \\
\hline $\begin{array}{l}12 \text { I think others make } \\
\text { judgments about me by the } \\
\text { kinds of products and brands I } \\
\text { buy. }\end{array}$ & 315 & 54.4 & 100 & 17.3 & 46 & 7.9 & 66 & 11.4 & 52 & 9.0 & 2.03 & 1.37 \\
\hline $\begin{array}{l}13 \text { Buying a high priced brand } \\
\text { makes me feel good about } \\
\text { myself. }\end{array}$ & 269 & 46.5 & 116 & 20.0 & 25 & 4.3 & 81 & 14.0 & 88 & 15.2 & 2.31 & 1.53 \\
\hline $\begin{array}{l}14 \text { Your friends will think you } \\
\text { are stingy if you consistently } \\
\text { buy the lowest priced version of } \\
\text { a product. }\end{array}$ & 296 & 51.1 & 99 & 17.1 & 56 & 9.7 & 63 & 10.9 & 65 & 11.2 & 2.14 & 1.43 \\
\hline $\begin{array}{l}15 \text { People notice when you buy } \\
\text { the most expensive brand of a } \\
\text { product. }\end{array}$ & 176 & 30.4 & 78 & 13.5 & 52 & 9.0 & 135 & 23.3 & 138 & 23.8 & 2.97 & 1.59 \\
\hline $\begin{array}{l}16 \text { The money saved by finding } \\
\text { low prices is usually not worth } \\
\text { the time and effort. }\end{array}$ & 178 & 30.7 & 110 & 19.0 & 51 & 8.8 & 102 & 17.6 & 138 & 23.8 & 2.85 & 1.59 \\
\hline $\begin{array}{l}17 \text { The time it takes to find low } \\
\text { prices is usually not worth the } \\
\text { effort. }\end{array}$ & 158 & 27.3 & 124 & 21.4 & 37 & 6.4 & 102 & 17.6 & 158 & 27.3 & 2.96 & 1.61 \\
\hline $\begin{array}{l}18 \text { I would never shop at more } \\
\text { than one store to find low } \\
\text { prices. }\end{array}$ & 141 & 24.4 & 106 & 18.3 & 39 & 6.7 & 105 & 18.1 & 188 & 32.5 & 3.16 & 1.62 \\
\hline $\begin{array}{l}19 \text { I am not willing to go to } \\
\text { extra effort to find lower price. }\end{array}$ & 151 & 26.1 & 89 & 15.4 & 56 & 9.7 & 100 & 17.3 & 183 & 31.6 & 3.13 & 1.62 \\
\hline
\end{tabular}


Table 2 (Cont.): Descriptive statistics of the expressions

\begin{tabular}{|c|c|c|c|c|c|c|c|c|c|c|c|c|}
\hline $\begin{array}{l}20 \text { I will shop at more than one } \\
\text { store to take advantage of low } \\
\text { prices }\end{array}$ & 225 & 38.9 & 103 & 17.8 & 38 & 6.6 & 116 & 20.0 & 97 & 16.8 & 2.58 & 1.56 \\
\hline $\begin{array}{l}21 \text { I am more likely to buy } \\
\text { brands that are on sale. }\end{array}$ & 182 & 31.4 & 75 & 13.0 & 31 & 5.4 & 137 & 23.7 & 154 & 26.6 & 3.01 & 1.64 \\
\hline $\begin{array}{l}22 \text { Compared to most people, I } \\
\text { am more likely to buy brands } \\
\text { that are on sale. }\end{array}$ & 273 & 47.2 & 54 & 9.3 & 56 & 9.7 & 86 & 14.9 & 110 & 19.0 & 2.49 & 1.62 \\
\hline $\begin{array}{l}\text { 23One should try to buy the } \\
\text { brand that's on sale. }\end{array}$ & 175 & 30.2 & 55 & 9.5 & 94 & 16.2 & 92 & 15.9 & 163 & 28.2 & 3.02 & 1.61 \\
\hline $\begin{array}{l}24 \text { I have favorite brands, but } \\
\text { most of the time I buy the } \\
\text { brand that's on sale. }\end{array}$ & 263 & 45.4 & 69 & 11.9 & 37 & 6.4 & 92 & 15.9 & 118 & 20.4 & 2.54 & 1.64 \\
\hline $\begin{array}{l}25 \text { If a product is on sale, that } \\
\text { can be a reason for me to buy it }\end{array}$ & 299 & 51.6 & 78 & 13.5 & 46 & 7.9 & 64 & 11.1 & 92 & 15.9 & 2.26 & 1.55 \\
\hline $\begin{array}{l}26 \text { When I buy a brand that's on } \\
\text { sale, I feel that I am getting a } \\
\text { good deal. }\end{array}$ & 148 & 25.6 & 78 & 13.5 & 50 & 8.6 & 115 & 19.9 & 188 & 32.5 & 3.20 & 1.62 \\
\hline $\begin{array}{l}27 \text { The price of a product is a } \\
\text { good indicator of its quality }\end{array}$ & 196 & 33.9 & 113 & 19.5 & 73 & 12.6 & 110 & 19.0 & 87 & 15.0 & 2.62 & 1.48 \\
\hline $\begin{array}{l}28 \text { The old saying "you get what } \\
\text { you pay for" is generally true }\end{array}$ & 173 & 29.9 & 104 & 18.0 & 109 & 18.8 & 113 & 19.5 & 80 & 13.8 & 2.69 & 1.43 \\
\hline $\begin{array}{l}29 \text { You always have to pay a bit } \\
\text { more for the best. }\end{array}$ & 191 & 33.0 & 109 & 18.8 & 72 & 12.4 & 123 & 21.2 & 84 & 14.5 & 2.65 & 1.48 \\
\hline $\begin{array}{l}\text { 30It is generally said that the } \\
\text { higher the price of a product, the } \\
\text { higher the quality. }\end{array}$ & 193 & 33.3 & 84 & 14.5 & 71 & 12.3 & 106 & 18.3 & 125 & 21.6 & 2.80 & 1.58 \\
\hline $\begin{array}{l}31 \text { I am very concerned about } \\
\text { low prices, but I am equally } \\
\text { concerned about product } \\
\text { quality. }\end{array}$ & 186 & 32.1 & 71 & 12.3 & 39 & 6.7 & 140 & 24.2 & 143 & 24.7 & 2.97 & 1.63 \\
\hline $\begin{array}{l}32 \text { When purchasing a product, } \\
\text { I always try to maximize the } \\
\text { quality I get for the money I } \\
\text { spend. }\end{array}$ & 158 & 27.3 & 77 & 13.3 & 30 & 5.2 & 140 & 24.2 & 174 & 30.1 & 3.16 & 1.63 \\
\hline $\begin{array}{l}33 \text { When shopping, I compare } \\
\text { the prices of different brands to } \\
\text { be sure I get the best value for } \\
\text { the money I pay. }\end{array}$ & 218 & 37.7 & 88 & 15.2 & 40 & 6.9 & 110 & 19.0 & 123 & 21.2 & 2.71 & 1.62 \\
\hline $\begin{array}{l}34 \text { When I buy products, I like } \\
\text { to be sure that I am getting my } \\
\text { money's worth. }\end{array}$ & 199 & 34.4 & 64 & 11.1 & 57 & 9.8 & 126 & 21.8 & 133 & 23.0 & 2.88 & 1.62 \\
\hline $\begin{array}{l}35 \text { When I shop, I usually } \\
\text { compare the "price per ounce" } \\
\text { information for brands I } \\
\text { normally buy. }\end{array}$ & 250 & 43.2 & 87 & 15.0 & 56 & 9.7 & 106 & 18.3 & 80 & 13.8 & 2.45 & 1.52 \\
\hline $\begin{array}{l}36 \text { I generally shop around for } \\
\text { lower prices on products, but } \\
\text { they still must meet certain } \\
\text { quality requirements before I } \\
\text { buy them. }\end{array}$ & 233 & 40.2 & 93 & 16.1 & 40 & 6.9 & 101 & 17.4 & 112 & 19.3 & 2.60 & 1.60 \\
\hline $\begin{array}{l}37 \text { I always check prices at the } \\
\text { store to be sure I get the best } \\
\text { value for the money I spend. }\end{array}$ & 222 & 38.3 & 84 & 14.5 & 51 & 8.8 & 112 & 19.3 & 110 & 19.0 & 2.66 & 1.59 \\
\hline
\end{tabular}

According to Table 2, the expressions with the highest agreement level are as follows:

- When I buy a brand that's on sale, I feel that I am getting a good deal.

- When purchasing a product, I always try to maximize the quality I get for the money I spend.

- I would never shop at more than one store to find low prices.

- I am not willing to go to extra effort to find lower price.

- One should try to buy the brand that's on sale. 
The expressions with the lowest agreement level are as follows:

- I buy expensive brand of a product just because I know other people will notice

- I think others make judgments about me by the kinds of products and brands I buy.

- I'm considered somewhat of an expert when it comes to knowing the prices of products.

- Even for a relatively inexpensive product, I think that buying a costly brand is impressive

- Your friends will think you are stingy if you consistently buy the lowest priced version of a product.

\subsection{Validity and Reliability Results of Price Perception Scale}

Exploratory factor analysis technique is used to find out the construct validity of a scale statistically. First of all, KMO and Bartlett test are conducted to understand whether the scale is suitable for factor analysis. KMO coefficient is calculated to test sample size. In factor analysis, the distribution in the population is also expected to be normal and this is examined with Bartlett test. In this context, KMO test measurement result should be close to 1.000 and Bartlett Sphericity test result should be statistically significant. Scree plot, which is the scree diagram of eigenvalues of the factors, and explained variance ratio are used in determining the total factor number of the scale. In factor analysis, factor load values should be checked in the process of assigning item to the scale or removing item from the scale. Factor load value is a coefficient which explains the relationship of items with factors. Items are expected to have high load values in the factor they are included in. In cases when the factor load of each item is smaller than 0.30 or when the difference between the factor loads of the item in question is smaller than 0.10 (overlapping), the item is removed from the scale and the analysis is continued (Jeong, 2004). KMO and Bartlett Test results for Price Perception Scale are shown in Table 3.

Table 3: KMO and Bartlett Test results for Price Perception Scale

\begin{tabular}{|c|c|c|}
\hline \multicolumn{2}{|c|}{ Kaiser-Meyer-Olkin Measure of Sampling Adequacy. } & .923 \\
\hline \multirow{3}{*}{ Bartlett's Test of Sphericity } & Approx. Chi-Square & 15978.416 \\
\hline & df & 666 \\
\hline & Sig. & 0.000 \\
\hline
\end{tabular}

In the factor analysis made for Price Perception Scale, KMO value was calculated as 0.923. According to this, sample size is suitable for factor analysis (KMO $>0.500)$. Within the scope of the Bartlett test, $X^{2}$ value was found as 15978.416 and statistically significant $(p<0.05)$. According to $\mathrm{KMO}$ and Bartlett test results, it was concluded that the data were suitable for factor analysis.

Factor analysis results for Price Perception Scale are as in Table 4. 
Table 4: Factor Analysis results for Price Perception Scale

\begin{tabular}{|c|c|c|c|c|}
\hline Subscale & Item & Factor load & Explained variance & Cronbach's Alpha \\
\hline \multirow{9}{*}{ Prestige Sensitivity } & FA8 & .811 & \multirow{9}{*}{16.237} & \multirow{9}{*}{.929} \\
\hline & FA11 & .803 & & \\
\hline & FA12 & .797 & & \\
\hline & FA10 & .794 & & \\
\hline & FA9 & .790 & & \\
\hline & FA13 & .779 & & \\
\hline & FA14 & .757 & & \\
\hline & FA7 & .748 & & \\
\hline & FA15 & .662 & & \\
\hline \multirow{7}{*}{ Value consciousness } & FA33 & .832 & \multirow{7}{*}{12.399} & \multirow{7}{*}{.904} \\
\hline & FA34 & .825 & & \\
\hline & FA35 & .813 & & \\
\hline & FA37 & .804 & & \\
\hline & FA32 & .748 & & \\
\hline & FA36 & .728 & & \\
\hline & FA31 & .692 & & \\
\hline \multirow{6}{*}{ Price mavenism } & FA1 & .874 & \multirow{6}{*}{12.176} & \multirow{6}{*}{.930} \\
\hline & FA2 & .855 & & \\
\hline & FA4 & .844 & & \\
\hline & FA6 & .838 & & \\
\hline & FA3 & .834 & & \\
\hline & FA5 & .794 & & \\
\hline \multirow{6}{*}{ Sale proneness } & FA24 & .842 & \multirow{6}{*}{11.664} & \multirow{6}{*}{.917} \\
\hline & FA25 & .823 & & \\
\hline & FA21 & .817 & & \\
\hline & FA22 & .796 & & \\
\hline & FA23 & .782 & & \\
\hline & FA26 & .772 & & \\
\hline \multirow{5}{*}{ Price consciousness } & FA17 & .873 & \multirow{5}{*}{10.180} & \multirow{5}{*}{.913} \\
\hline & FA19 & .867 & & \\
\hline & FA18 & .844 & & \\
\hline & FA16 & .776 & & \\
\hline & FA20 & .654 & & \\
\hline \multirow{4}{*}{ Price-quality relationship } & FA30 & .810 & \multirow{4}{*}{8.312} & \multirow{4}{*}{.902} \\
\hline & FA28 & .807 & & \\
\hline & FA29 & .799 & & \\
\hline & FA27 & .787 & & \\
\hline
\end{tabular}

According to the results of the factor analysis conducted, the scale was found to have 6 factors. Prestige Sensitivity subscale consists of 9 items, factor loads of which varied between 0.662 and 0.811. The subscale's rate of explaining the total variance was $16.237 \%$, while its reliability coefficient was 0.929 . According to this result, the subscale has very high reliability level. Value consciousness subscale consists of 7 items, factor loads of which varied between 0.692 and 0.832 . The subscale's rate of explaining the total variance was $12.399 \%$, while its reliability coefficient was 0.904. According to this result, the subscale has very high reliability level. Price mavenism subscale consists of 6 items, factor loads of which varied between 0.794 and 0.874 . The subscale's rate of explaining the total variance was $12.176 \%$, while its reliability coefficient was 0.930 . According to this result, the subscale has very high reliability level. Sale proneness subscale consists of 6 items, factor loads of which varied between 0.772 and 0.842 . The subscale's rate of explaining the total variance was $11.664 \%$, while its reliability coefficient was 0.917 . According to this result, the subscale has very high level of reliability. Price consciousness subscale consists of 5 items, factor loads of which varied between 0.654 and 0.873 . The subscale's rate of explaining the total variance was $10.180 \%$, while its reliability coefficient was 0.913 . According to this result, the subscale has very high reliability level. Price-quality relationship subscale consists of 4 items, factor loads of which varied between 0.787 and 0.810 . The subscale's rate of explaining the total variance was $8.132 \%$, while its reliability coefficient was 0.902 . According to this result, the subscale has very high level of reliability. 
Within the context of the study, confirmatory factor analysis was used and the structural validity of Price Perception Scale was examined. In confirmatory factor analysis, the relationships between observed variables and latent variables are examined simultaneously on a model. According to factor analysis result, it is possible to understand to what extent the factor structure of the measurement tool is compatible with the collected data (Kline, 2011). Fit values calculated to assess the six-factor structure of Price Perception Scale is shown in Table 5.

Table 5: Fit Values of The Six-Factor Structure of Price Perception Scale

\begin{tabular}{|c|c|c|c|c|}
\hline Criterion & Good fit & Acceptable fit & $\begin{array}{l}\text { Values } \\
\text { obtained }\end{array}$ & References \\
\hline$\left(\chi^{2} / \mathrm{sd}\right)$ & $\leq 3$ & $\leq 4-5$ & 2.42 & $\begin{array}{c}\text { Carmines and McIver, } \\
\text { 1981; Marsh and } \\
\text { Hocevar, } 1985\end{array}$ \\
\hline RMSEA & $\leq 0.05$ & $0.06-0.08$ & 0.05 & \multirow{2}{*}{$\begin{array}{c}\text { Browne and Cudeck, } \\
1993 \\
\end{array}$} \\
\hline SRMR & $\leq 0.05$ & $0.06-0.08$ & 0.06 & \\
\hline CFI & $\geq 0.95$ & $0.90-0.94$ & 0.95 & $\begin{array}{l}\text { McDonald and Marsh, } \\
\text { 1990; Bentler, } 1990\end{array}$ \\
\hline TLI & $\geq 0.95$ & $0.90-0.94$ & 0.94 & $\begin{array}{l}\text { Bentler and Bonett, } \\
1980\end{array}$ \\
\hline GFI & $\geq 0.90$ & $0.89-0.85$ & 0.88 & \multirow{2}{*}{$\begin{array}{c}\text { Tanaka and Huba, } \\
1985 ; \\
\text { Jöreskog and Sörbom, } \\
1984\end{array}$} \\
\hline AGFI & $\geq 0.90$ & $0.89-0.80$ & 0.86 & \\
\hline
\end{tabular}

When the Table is examined, as a result of the confirmatory factor analysis, it was observed that the tested model was statistically significant according to standardized estimation results $\left(\chi^{2}\right.$ $=1461.24 ; \mathrm{Sd}=603 ; \mathrm{p}<0.01)$. Goodness of fit values calculated to test the model met the criteria and the six-factor structure was confirmed. According to goodness of fit values, the six-factor structure Price Perception Scale is compatible with the collected data in acceptable levels in general. As a result of the factor analysis, factor loads of the items in the factors of price mavenism, prestige sensitivity, price consciousness, sale proneness, price-quality relationship and value consciousness were found to be between the ranges of $0.79-0.88 ; 0.66-0.87 ; 0.63-0.92 ; 0.72-0.88 ; 0.80-0.87$ and $0.59-0.87$, respectively. Figure 2 shows the tested six factor model. All path coefficients shown in the model were found to be statistically significant at the level of $\mathrm{p}<0.001$.

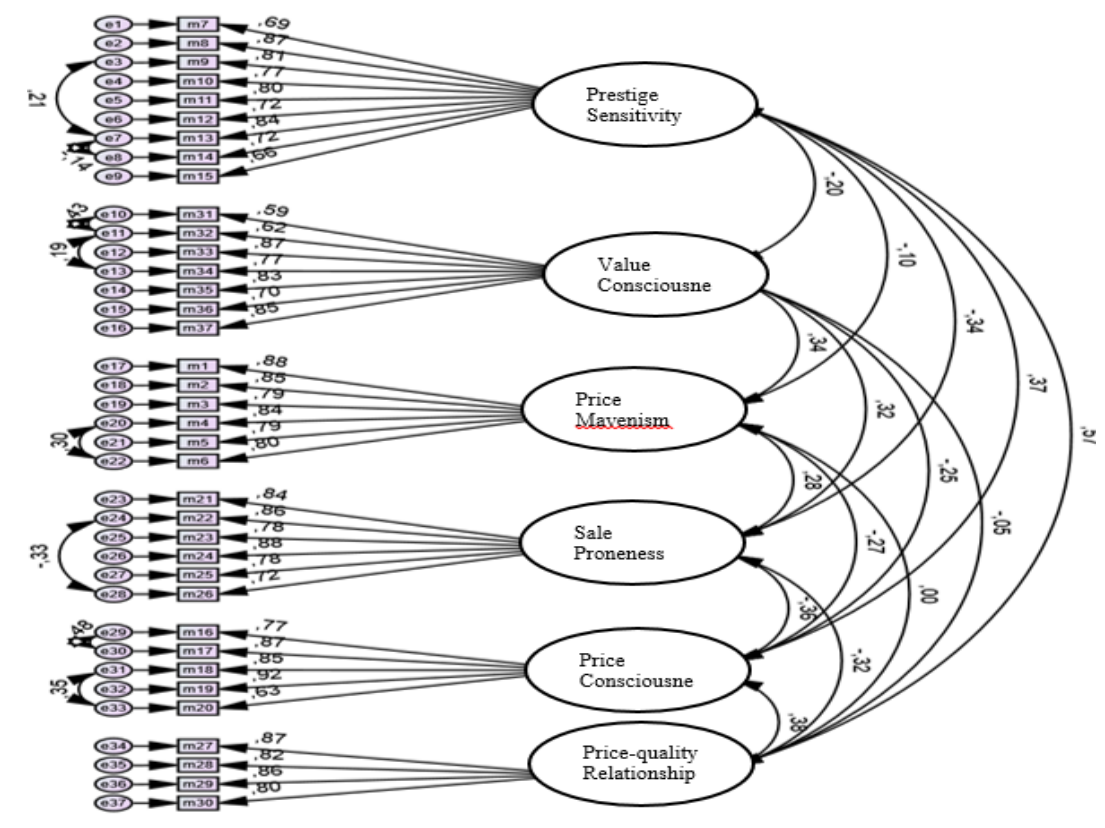

Figure 2: Confirmatory Factor Analysis Diagram of Price Perception Scale 
Cronbach Alpha coefficients were calculated and the reliability of Price Perception Scale was examined. Alpha coefficient values close to 1 indicate that internal consistency reliability is high. Alpha coefficients between 0.60 and 0.80 show that the scale is reliable and alpha coefficients between 0.81 and 1.00 show that the scale is highly reliable (Özdamar, 2004).

Cronbach's alpha coefficient shows the reliability level of the scale. The coefficient varies between 0 and 1. Depending on the Alpha $(\alpha)$ coefficient, reliability of the scale is interpreted as follows (Tavşancıl, 2005):

$\cdot .00 \leq \alpha<.40$ not reliable,

- $.40 \leq \alpha<.60$ low reliability,

- $.60 \leq \alpha<.80$ very reliable,

- $.80 \leq \alpha<1.00$ highly reliable.

Alpha coefficients of the scale calculated for price mavenism, prestige sensitivity, price consciousness, sale proneness, price-quality relationship and value consciousness factors were 0.93; $0.93 ; 0.91 ; 0.92 ; 0.90$ and 0.90 , respectively. In a different study conducted in Turkey, these values were found as $0.88 ; 0.85 ; 0.75 ; 0.80 ; 0.71 ; 0.80$, respectively (Leblebicioğlu and Bilgen, 2019: 148149). In another study, the values were found as $0.87 ; 0.86 ; 0.84 ; 0.64,0.72$ and 0.60 , respectively (Yaraş, 2008: 288). The coefficients obtained showed that the price perception scale was highly reliable and the items of the scale were compatible with each other.

\subsection{Statistical Analysis of Data}

Descriptive analysis techniques were used to examine the scores participants got from Price Perception Scale within the context of the study. Independent samples t test was used to compare the scores of Price Perception Scale in terms of the variable of gender, while one way ANOVA was used to compare the scores in terms of the variables of monthly income, age, educational status and occupation. Before the analyses were conducted, normality distribution was checked. In data with a large sample, Skewness coefficients within the range of \pm 3 and Kurtosis coefficients within the range of \pm 10 show that the data have a normal distribution (Kline, 2011: 63). Skewness coefficients ($0.05<\mathrm{SC}<0.82)$ and the Kurtosis coefficients $(-1.42<\mathrm{KC}<-0.61)$ calculated for the scores obtained from the measurement tool were within the specified range.

Since sample size has a significant effect on statistical significance value, it is recommended for effect size to be reported in scientific studies. In order to specify the significance of the difference obtained with the comparison of two or more groups, Cohen $\mathrm{d}$ and eta square effect values are reported. In general, $d=0.2$ and $\eta 2=0.01$ show small effect, while $d=0.5$ nd $\eta 2=0.06$ show moderate effect and $d=0.8$ and $\eta 2=0.14$ show a large effect value (Cohen, 1988; Field, 2013). The data were analyzed by using SPSS 21.0 .

\section{RESULTS}

Table 6 shows descriptive values of the scores participants got From Price Perception Scale.

Table 6: Descriptive Values of The Scores Participants Got From Price Perception Scale

\begin{tabular}{|lccccc|}
\hline Variables & $\mathbf{N}$ & Min. & Max. & $\overline{\boldsymbol{X}}$ & Sd \\
\hline Price mavenism & 579 & 1.00 & 5.00 & 2.29 & 1.23 \\
\hline Prestige sensitivity & 579 & 1.00 & 5.00 & 2.30 & 1.18 \\
\hline Price consciousness & 579 & 1.00 & 5.00 & 3.10 & 1.38 \\
\hline Sale proneness & 579 & 1.00 & 5.00 & 2.75 & 1.36 \\
\hline Price-quality relationship & 579 & 1.00 & 5.00 & 2.69 & 1.31 \\
\hline Value consciousness & 579 & 1.00 & 5.00 & 2.78 & 1.27 \\
\hline
\end{tabular}


When the Table is examined, it can be seen that the participants' price mavenism, prestige sensitivity, price consciousness, sale proneness, price-quality relationship and value consciousness scores differ between 1 and 5. Price mavenism, prestige sensitivity, price consciousness, sale proneness, price-quality relationship and value consciousness average scores were calculated as 2.29 $(\mathrm{Sd}=1.23), 2.30(\mathrm{Sd}=1.18), 3.10(\mathrm{Sd}=1.38), 2.75(\mathrm{Sd}=1.36), 2.69(\mathrm{Sd}=1.31)$ and $2.78(\mathrm{Sd}=1.27)$, respectively. Musellim (2021) reached the following results, respectively: 2.89 ( $\mathrm{Sd}=0.72) ; 0.72$ $(\mathrm{Sd}=0.93) ; 3.63(\mathrm{Sd}=0.83) ; 3.38(\mathrm{Sd}=0.83) ; 3.00(\mathrm{Sd}=0.87)$ and $2.10(\mathrm{Sd}=0.86)$. According to these values, participants had low prestige sensitivity level; moderate level of price consciousness, value consciousness, price mavenism, price-quality relationship and higher than moderate sale proneness (Musellim, 2021: 56-59). In this study, the values obtained showed that participants had low level of price mavenism and prestige sensitivity perceptions; while they had moderate level of price consciousness, sale proneness, price-quality relationship and value consciousness perceptions.

Participants' price perception score averages, standard deviations and t test results in terms of gender are seen in Table 7.

Table 7: Price Perception Score Averages, Standard Deviations and T Test Results in Terms of Gender

\begin{tabular}{|c|c|c|c|c|c|c|c|}
\hline Variable & Gender & $\mathrm{N}$ & $\bar{X}$ & $\mathrm{Sd}$ & $\mathrm{t}$ & $\mathrm{p}$ & Cohen d \\
\hline \multirow{2}{*}{ Price mavenism } & Female & 312 & 2.15 & 1.18 & \multirow{2}{*}{-2.94} & \multirow{2}{*}{$.003^{*}$} & \multirow{2}{*}{0.24} \\
\hline & Male & 267 & 2.45 & 1.28 & & & \\
\hline \multirow{2}{*}{$\begin{array}{l}\text { Prestige } \\
\text { Sensitivity }\end{array}$} & Female & 312 & 2.18 & 1.16 & \multirow{2}{*}{-2.52} & \multirow{2}{*}{$.012 *$} & \multirow{2}{*}{0.21} \\
\hline & Male & 267 & 2.43 & 1.19 & & & \\
\hline \multirow{2}{*}{$\begin{array}{l}\text { Price } \\
\text { consciousness }\end{array}$} & Female & 312 & 2.94 & 1.36 & \multirow{2}{*}{-3.19} & \multirow{2}{*}{$.001 *$} & \multirow{2}{*}{0.26} \\
\hline & Male & 267 & 3.30 & 1.37 & & & \\
\hline \multirow{2}{*}{ Sale proneness } & Female & 312 & 2.92 & 1.40 & \multirow{2}{*}{3.17} & \multirow{2}{*}{$.002 *$} & \multirow{2}{*}{0.27} \\
\hline & Male & 267 & 2.56 & 1.28 & & & \\
\hline \multirow{2}{*}{$\begin{array}{l}\text { Price-quality } \\
\text { relationship }\end{array}$} & Female & 312 & 2.50 & 1.30 & \multirow{2}{*}{-3.91} & \multirow{2}{*}{$.000 *$} & \multirow{2}{*}{0.32} \\
\hline & Male & 267 & 2.92 & 1.30 & & & \\
\hline \multirow{2}{*}{$\begin{array}{l}\text { Value } \\
\text { consciousness }\end{array}$} & Female & 312 & 2.79 & 1.27 & \multirow{2}{*}{0.33} & \multirow{2}{*}{.745} & \multirow{2}{*}{0.02} \\
\hline & Male & 267 & 2.76 & 1.29 & & & \\
\hline
\end{tabular}

$* \mathrm{p}<0.05$

When the Table is examined, it can be seen that there is no significant difference in value consciousness average scores in terms of gender $(p>0.05)$. However, a significant gender related difference was found in price mavenism, prestige sensitivity, price consciousness, sale proneness and price-quality relationship average scores $(p<0.05)$. The variable of gender has a small influence on price perception in general. Price mavenism, prestige sensitivity, price consciousness and pricequality relationship average scores of male participants were found to be significantly higher, while sale proneness average scores of female participants were found to be significantly higher.

Table 8 shows participants' price perception score averages, standard deviations and ANOVA results in terms of monthly individual net income. 
Table 8: Price Perception Score Averages, Standard Deviations and ANOVA Results in Terms of Monthly Individual Net Income

\begin{tabular}{|c|c|c|c|c|c|c|c|c|c|}
\hline Variable & & $\begin{array}{l}\text { Monthly individual net } \\
\text { income }\end{array}$ & $\mathrm{N}$ & $\bar{X}$ & $\mathrm{Sd}$ & $\mathrm{F}$ & $\mathrm{p}$ & $\eta^{2}$ & Post-Hoc ${ }^{\text {a }}$ \\
\hline \multirow{5}{*}{ Price mavenism } & 1. & Less than $2021 \mathrm{TL}$ & 113 & 3.00 & 1.18 & \multirow{5}{*}{31.14} & \multirow{5}{*}{$<0.01$} & \multirow{5}{*}{0.18} & \multirow{5}{*}{$\begin{array}{l}1>5,1>4 \\
2>5,2>4 \\
\quad 3>5\end{array}$} \\
\hline & 2. & $2021-5000 \mathrm{TL}$ & 151 & 2.65 & 1.23 & & & & \\
\hline & 3. & $5001-8000 \mathrm{TL}$ & 168 & 2.09 & 1.22 & & & & \\
\hline & 4. & $8001-11000 \mathrm{TL}$ & 110 & 1.63 & 0.83 & & & & \\
\hline & 5. & More than $11000 \mathrm{TL}$ & 37 & 1.47 & 0.63 & & & & \\
\hline \multirow{5}{*}{$\begin{array}{l}\text { Prestige } \\
\text { sensitivity }\end{array}$} & 1. & Less than $2021 \mathrm{TL}$ & 113 & 2.37 & 1.11 & \multirow{5}{*}{27.44} & \multirow{5}{*}{$<0.01$} & \multirow{5}{*}{0.16} & \multirow{5}{*}{$\begin{array}{c}5>1,5>2,5>3 \\
4>1,4>2,4>3 \\
3>1 \\
2>1\end{array}$} \\
\hline & 2. & $2021-5000 \mathrm{TL}$ & 151 & 1.67 & 0.70 & & & & \\
\hline & 3. & $5001-8000 \mathrm{TL}$ & 168 & 2.21 & 1.15 & & & & \\
\hline & 4. & $8001-11000 \mathrm{TL}$ & 110 & 2.91 & 1.27 & & & & \\
\hline & 5. & More than $11000 \mathrm{TL}$ & 37 & 3.14 & 1.34 & & & & \\
\hline \multirow{5}{*}{$\begin{array}{l}\text { Price } \\
\text { consciousness }\end{array}$} & 1. & Less than $2021 \mathrm{TL}$ & 113 & 2.37 & 1.04 & \multirow{5}{*}{26.52} & \multirow{5}{*}{$<0.01$} & \multirow{5}{*}{0.16} & \multirow{5}{*}{$\begin{array}{c}5>1,5>2,5>3 \\
4>1,4>2,4>3 \\
3>1\end{array}$} \\
\hline & 2. & $2021-5000 \mathrm{TL}$ & 151 & 2.82 & 1.26 & & & & \\
\hline & 3. & $5001-8000 \mathrm{TL}$ & 168 & 3.15 & 1.45 & & & & \\
\hline & 4. & $8001-11000 \mathrm{TL}$ & 110 & 3.83 & 1.27 & & & & \\
\hline & 5. & More than $11000 \mathrm{TL}$ & 37 & 4.14 & 1.00 & & & & \\
\hline \multirow{5}{*}{ Sale sensitivity } & 1. & Less than $2021 \mathrm{TL}$ & 113 & 3.66 & 1.04 & \multirow{5}{*}{62.31} & \multirow{5}{*}{$<0.01$} & \multirow{5}{*}{0.31} & \multirow{5}{*}{$\begin{array}{l}1>5,1>4,1>3 \\
2>5,2>4,2>3 \\
\quad 3>5,3>4\end{array}$} \\
\hline & 2. & $2021-5000 \mathrm{TL}$ & 151 & 3.39 & 1.29 & & & & \\
\hline & 3. & $5001-8000 \mathrm{TL}$ & 168 & 2.45 & 1.25 & & & & \\
\hline & 4. & $8001-11000 \mathrm{TL}$ & 110 & 1.83 & 0.94 & & & & \\
\hline & 5. & More than $11000 \mathrm{TL}$ & 37 & 1.50 & 0.65 & & & & \\
\hline \multirow{5}{*}{$\begin{array}{l}\text { Price-quality } \\
\text { relationship }\end{array}$} & 1. & Less than $2021 \mathrm{TL}$ & 113 & 2.86 & 1.25 & \multirow{5}{*}{20.84} & \multirow{5}{*}{$<0.01$} & \multirow{5}{*}{0.13} & \multirow{5}{*}{$\begin{array}{l}5>1,5>2,5>3 \\
4>1,4>2,4>3\end{array}$} \\
\hline & 2. & $2021-5000 \mathrm{TL}$ & 151 & 2.43 & 1.12 & & & & \\
\hline & 3. & $5001-8000 \mathrm{TL}$ & 168 & 2.53 & 1.29 & & & & \\
\hline & 4. & $8001-11000 \mathrm{TL}$ & 110 & 3.18 & 1.34 & & & & \\
\hline & 5. & More than $11000 \mathrm{TL}$ & 37 & 3.78 & 0.98 & & & & \\
\hline \multirow{5}{*}{$\begin{array}{l}\text { Value } \\
\text { consciousness }\end{array}$} & 1. & Less than $2021 \mathrm{TL}$ & 113 & 3.60 & 1.04 & \multirow{5}{*}{18.48} & \multirow{5}{*}{$<0.01$} & \multirow{5}{*}{0.11} & \\
\hline & 2. & $2021-5000 \mathrm{TL}$ & 151 & 2.78 & 1.28 & & & & \\
\hline & 3. & $5001-8000 \mathrm{TL}$ & 168 & 2.52 & 1.19 & & & & $1>5,1>4,1>3,1>2$ \\
\hline & 4. & $8001-11000 \mathrm{TL}$ & 110 & 2.44 & 1.24 & & & & \\
\hline & 5. & More than $11000 \mathrm{TL}$ & 37 & 2.36 & 1.32 & & & & \\
\hline
\end{tabular}

When the Table is examined, a significant difference was found in price mavenism, prestige sensitivity, price consciousness, sale proneness, price-quality relationship and value consciousness score averages in terms of monthly individual net income $(\mathrm{p}<0.05)$. Monthly individual net income variable has a broad influence on price perception in general. In general, price mavenism and sale proneness score averages of the participants with a monthly income of "less than 2012 TL", "20215000 TL" and "5001-8000 TL" were found to be higher. Participants with a monthly income of "8001 - $11000 \mathrm{TL}$ " and "more than 11000 TL" were found to have higher prestige sensitivity, price consciousness and price-quality relationship score averages. Lastly, value consciousness average scores of the participants with a monthly income of "less than 2021 TL" were found to be higher than those of the participants with a monthly income of "2021-5000 TL", "5001-8000 TL", "8001-11000 TL" and "more than 11000 TL"

Table 9 shows participants' price perception score averages, standard deviations and ANOVA results in terms of age group. 
Table 9: Price Perception Score Averages, Standard Deviations and ANOVA Results in Terms of Age Group

\begin{tabular}{|c|c|c|c|c|c|c|c|c|c|}
\hline Variables & & $\begin{array}{l}\text { Age } \\
\text { group }\end{array}$ & $\mathrm{N}$ & $\bar{X}$ & $\mathrm{Sd}$ & $\mathrm{F}$ & $\mathrm{p}$ & $\eta^{2}$ & Post-Hoc ${ }^{\mathrm{a}}$ \\
\hline \multirow{5}{*}{ Price mavenism } & 1. & $18-25$ & 132 & 3.06 & 1.20 & \multirow{5}{*}{19.43} & \multirow{5}{*}{$<0.01$} & \multirow{5}{*}{0.12} & \multirow{5}{*}{$1>2,1>3,1>4,1>5$} \\
\hline & 2. & $26-35$ & 131 & 1.99 & 1.11 & & & & \\
\hline & 3. & $36-45$ & 138 & 2.07 & 1.23 & & & & \\
\hline & 4. & $46-55$ & 125 & 2.12 & 1.12 & & & & \\
\hline & 5. & $56+$ & 53 & 2.03 & 1.11 & & & & \\
\hline \multirow{5}{*}{$\begin{array}{l}\text { Prestige } \\
\text { sensitivity }\end{array}$} & 1. & $18-25$ & 132 & 2.40 & 1.08 & \multirow{5}{*}{1.34} & \multirow{5}{*}{0.25} & \multirow{5}{*}{0.01} & \multirow{5}{*}{ - } \\
\hline & 2. & $26-35$ & 131 & 2.32 & 1.24 & & & & \\
\hline & 3. & $36-45$ & 138 & 2.37 & 1.26 & & & & \\
\hline & 4. & $46-55$ & 125 & 2.10 & 1.15 & & & & \\
\hline & 5. & $56+$ & 53 & 2.24 & 1.11 & & & & \\
\hline \multirow{5}{*}{$\begin{array}{l}\text { Price } \\
\text { consciousness }\end{array}$} & 1. & $18-25$ & 132 & 2.42 & 1.16 & \multirow{5}{*}{12.13} & \multirow{5}{*}{$<0.01$} & \multirow{5}{*}{0.08} & \multirow{5}{*}{$5>1,4>1,3>1,2>1$} \\
\hline & 2. & $26-35$ & 131 & 3.44 & 1.30 & & & & \\
\hline & 3. & $36-45$ & 138 & 3.31 & 1.36 & & & & \\
\hline & 4. & $46-55$ & 125 & 3.20 & 1.41 & & & & \\
\hline & 5. & $56+$ & 53 & 3.20 & 1.48 & & & & \\
\hline \multirow{5}{*}{ Sale proneness } & 1. & $18-25$ & 132 & 3.33 & 1.09 & \multirow{5}{*}{8.37} & \multirow{5}{*}{$<0.01$} & \multirow{5}{*}{0.06} & \multirow{5}{*}{$1>2,1>3,1>4,1>5$} \\
\hline & 2. & $26-35$ & 131 & 2.67 & 1.39 & & & & \\
\hline & 3. & $36-45$ & 138 & 2.57 & 1.41 & & & & \\
\hline & 4. & $46-55$ & 125 & 2.58 & 1.36 & & & & \\
\hline & 5. & $56+$ & 53 & 2.42 & 1.38 & & & & \\
\hline \multirow{5}{*}{$\begin{array}{l}\text { Price-quality } \\
\text { relationship }\end{array}$} & 1. & $18-25$ & 132 & 3.02 & 1.21 & \multirow{5}{*}{3.34} & \multirow{5}{*}{0.01} & \multirow{5}{*}{0.02} & \multirow{5}{*}{$1>5$} \\
\hline & 2. & $26-35$ & 131 & 2.70 & 1.30 & & & & \\
\hline & 3. & $36-45$ & 138 & 2.64 & 1.36 & & & & \\
\hline & 4. & $46-55$ & 125 & 2.52 & 1.36 & & & & \\
\hline & 5. & $56+$ & 53 & 2.41 & 1.22 & & & & \\
\hline \multirow{5}{*}{$\begin{array}{l}\text { Value } \\
\text { consciousness }\end{array}$} & 1. & $18-25$ & 132 & 3.51 & 1.08 & \multirow{5}{*}{17.47} & \multirow{5}{*}{$<0.01$} & \multirow{5}{*}{0.11} & \\
\hline & 2. & $26-35$ & 131 & 2.47 & 1.21 & & & & \\
\hline & 3. & $36-45$ & 138 & 2.43 & 1.19 & & & & $1>2,1>3,1>4,1>5$ \\
\hline & 4. & $46-55$ & 125 & 2.76 & 1.33 & & & & \\
\hline & 5. & $56+$ & 53 & 2.62 & 1.28 & & & & \\
\hline
\end{tabular}

When the Table is examined, it can be understood that there is no significant difference in prestige sensitivity averages resulting from age groups $(p>0.05)$. A significant difference was found in price mavenism, price consciousness, sale proneness, price-quality relationship and value consciousness score averages resulting from age groups $(\mathrm{p}<0.05)$. The variable of age has a moderate effect on some price perception factors. Price mavenism, sale proneness and value consciousness score averages of the participants in "18- 25" age group were found to be higher than those of the participants in other age groups. Price consciousness score averages of the participants in "26-35", "36-45", "46-55" and "56+" age groups were found to be higher than those of the participants in "1825 " age group. Finally, it was found that price-quality relationship score averages of the participants in "18-25" age group were found to be higher than those of the participants in the "56+" age group.

Table 10 shows participants' price perception score averages, standard deviations and ANOVA results in terms of educational status. 
Table 10: Price Perception Score Averages, Standard Deviations and ANOVA Results in Terms of Educational Status

\begin{tabular}{|c|c|c|c|c|c|c|c|c|c|}
\hline Variables & & $\begin{array}{c}\text { Educational } \\
\text { Status }\end{array}$ & $\mathrm{N}$ & $\bar{X}$ & $\mathrm{Sd}$ & $\mathrm{F}$ & $\mathrm{p}$ & $\eta^{2}$ & Post-Hoc ${ }^{\mathrm{a}}$ \\
\hline \multirow{6}{*}{$\begin{array}{l}\text { Price } \\
\text { mavenism }\end{array}$} & 1. & Primary & 18 & 1.73 & 0.59 & \multirow{6}{*}{19.24} & \multirow{6}{*}{$<0.01$} & \multirow{6}{*}{0.14} & \multirow{6}{*}{$\begin{array}{l}2>6,2>5 \\
3>6,3>5 \\
4>6,4>5\end{array}$} \\
\hline & 2. & High school & 92 & 2.26 & 1.30 & & & & \\
\hline & 3. & Associate & 119 & 2.81 & 1.20 & & & & \\
\hline & 4. & Undergraduate & 219 & 2.52 & 1.25 & & & & \\
\hline & 5. & Master & 82 & 1.54 & 0.79 & & & & \\
\hline & 6. & Doctorate & 49 & 1.49 & 0.76 & & & & \\
\hline \multirow{6}{*}{$\begin{array}{l}\text { Prestige } \\
\text { sensitivity }\end{array}$} & 1. & Primary & 18 & 1.28 & 0.29 & \multirow{6}{*}{13.47} & \multirow{6}{*}{$<0.01$} & \multirow{6}{*}{0.11} & \multirow{6}{*}{$\begin{array}{l}6>1,6>2 \\
5>1,5>2 \\
4>1,4>2\end{array}$} \\
\hline & 2. & High school & 92 & 1.65 & 0.66 & & & & \\
\hline & 3. & Associate & 119 & 2.18 & 1.07 & & & & \\
\hline & 4. & Undergraduate & 219 & 2.51 & 1.22 & & & & \\
\hline & 5. & Master & 82 & 2.72 & 1.36 & & & & \\
\hline & 6. & Doctorate & 49 & 2.47 & 1.21 & & & & \\
\hline \multirow{6}{*}{$\begin{array}{l}\text { Price } \\
\text { consciousness }\end{array}$} & 1. & Primary & 18 & 2.52 & 1.07 & \multirow{6}{*}{20.20} & \multirow{6}{*}{$<0.01$} & \multirow{6}{*}{0.15} & \multirow{6}{*}{$\begin{aligned} 6>1, & 6>2,6>3, \\
6 & >4 ; \\
5>1, & 5>2,5>3, \\
5 & >4 ;\end{aligned}$} \\
\hline & 2. & High school & 92 & 2.64 & 1.21 & & & & \\
\hline & 3. & Associate & 119 & 2.71 & 1.17 & & & & \\
\hline & 4. & Undergraduate & 219 & 3.00 & 1.44 & & & & \\
\hline & 5. & Master & 82 & 3.90 & 1.14 & & & & \\
\hline & 6. & Doctorate & 49 & 4.27 & 1.08 & & & & \\
\hline \multirow{6}{*}{ Sale proneness } & 1. & Primary & 18 & 3.98 & 1.46 & \multirow{6}{*}{41.64} & \multirow{6}{*}{$<0.01$} & \multirow{6}{*}{0.27} & \multirow{6}{*}{$\begin{array}{c}1>6,1>5,1>4 \\
2>6,2>5,2>4 \\
3>6,3>5,3>4 \\
\quad 4>6,4>5\end{array}$} \\
\hline & 2. & High school & 92 & 3.52 & 1.37 & & & & \\
\hline & 3. & Associate & 119 & 3.41 & 1.16 & & & & \\
\hline & 4. & Undergraduate & 219 & 2.60 & 1.16 & & & & \\
\hline & 5. & Master & 82 & 1.80 & 1.08 & & & & \\
\hline & 6. & Doctorate & 49 & 1.55 & 0.75 & & & & \\
\hline \multirow{6}{*}{$\begin{array}{l}\text { Price-quality } \\
\text { relationship }\end{array}$} & 1. & Primary & 18 & 1.44 & 0.49 & \multirow{6}{*}{25.80} & \multirow{6}{*}{$<0.01$} & \multirow{6}{*}{0.18} & \\
\hline & 2. & High school & 92 & 1.67 & 0.85 & & & & $6>1,6>2$ \\
\hline & 3. & Associate & 119 & 2.59 & 1.28 & & & & $5>1,5>2$ \\
\hline & 4. & Undergraduate & 219 & 2.94 & 1.22 & & & & $4>1,4>2$ \\
\hline & 5. & Master & 82 & 3.36 & 1.33 & & & & $3>1,3>2$ \\
\hline & 6. & Doctorate & 49 & 3.09 & 1.31 & & & & \\
\hline \multirow{6}{*}{$\begin{array}{l}\text { Value } \\
\text { consciousness }\end{array}$} & 1. & Primary & 18 & 1.98 & 0.92 & \multirow{6}{*}{5.27} & & & \\
\hline & 2. & High school & 92 & 2.43 & 1.19 & & & & $6>1$ \\
\hline & 3. & Associate & 119 & 3.09 & 1.17 & & $<001$ & 004 & $5>1$ \\
\hline & 4. & Undergraduate & 219 & 2.71 & 1.21 & & $<0.01$ & 0.04 & $4>1$ \\
\hline & 5. & Master & 82 & 2.87 & 1.42 & & & & $3>1$ \\
\hline & 6. & Doctorate & 49 & 3.24 & 1.52 & & & & \\
\hline
\end{tabular}

When the Table is examined, a significant difference was found price mavenism, price consciousness, sale proneness, price-quality relationship and value consciousness score averages in terms of educational status $(\mathrm{p}<0.05)$. The variable of educational status has a broad effect on price perception factors in general. The participants with high school, associate and undergraduate degrees were found to have the highest price mavenism score averages, while the participants with master and doctorate degrees were found to have the lowest price mavenism score averages. In general, the participants with undergraduate, master and doctorate degrees were found to have the highest prestige sensitivity, price consciousness and price-quality relationship score averages, while the participants with primary education and high school education degrees were found to have the lowest prestige sensitivity, price consciousness and price-quality relationship score averages. The participants with primary education, associate and undergraduate degrees were found to have the highest sale proneness score averages, while the participants with master and doctorate degrees were found to have the lowest sale proneness score averages. In addition, it was found that the participants with associate, undergraduate, master and doctorate degrees were found to have higher score averages than the participants with primary education degree.

Table 11 shows participants' price perception score averages, standard deviations and ANOVA results in terms of occupation. 
Table 11: Price Perception Score Averages, Standard Deviations and ANOVA Results in Terms of Occupation

\begin{tabular}{|c|c|c|c|c|c|c|c|c|c|}
\hline Variables & & Occupation & $\mathrm{N}$ & $\bar{X}$ & $\mathrm{Sd}$ & $\mathrm{F}$ & $\mathrm{p}$ & $\eta^{2}$ & Post-Hoc ${ }^{\mathrm{a}}$ \\
\hline \multirow{10}{*}{ Price mavenism } & 1. & Officer & 56 & 3.73 & 1.04 & \multirow{10}{*}{32.35} & \multirow{10}{*}{$<0.01$} & \multirow{10}{*}{0.34} & \multirow{10}{*}{$\begin{array}{c}1>3,1>4,1>5,1>6,1>7,1>8 \\
1>9,1>10\end{array}$} \\
\hline & 2. & Student & 94 & 3.21 & 1.02 & & & & \\
\hline & 3. & Housewife & 53 & 1.99 & 1.18 & & & & \\
\hline & 4. & Manager & 51 & 1.68 & 0.89 & & & & \\
\hline & 5. & Worker & 55 & 1.82 & 0.86 & & & & \\
\hline & 6. & Teacher & 53 & 2.61 & 1.12 & & & & \\
\hline & 7. & Doctor & 56 & 1.74 & 0.99 & & & & \\
\hline & 8. & Engineer & 51 & 1.83 & 1.03 & & & & \\
\hline & 9. & Academician & 56 & 1.70 & 0.91 & & & & \\
\hline & 10. & Tradesmen & 54 & 1.81 & 1.02 & & & & \\
\hline \multirow{10}{*}{$\begin{array}{l}\text { Prestige } \\
\text { Sensitivity }\end{array}$} & 1. & Officer & 56 & 1.75 & 0.95 & \multirow{10}{*}{50.23} & \multirow{10}{*}{$<0.01$} & \multirow{10}{*}{0.44} & \multirow{10}{*}{$\begin{aligned} 4>1,4>2,4 & >3,4>5,4>6,4>8 \\
4 & >9,4>10 \\
7>1,7>2,7 & >3,7>5,7>6,7>8 \\
7 & >9,7>10\end{aligned}$} \\
\hline & 2. & Student & 94 & 2.49 & 1.09 & & & & \\
\hline & 3. & Housewife & 53 & 1.57 & 0.65 & & & & \\
\hline & 4. & Manager & 51 & 3.88 & 0.84 & & & & \\
\hline & 5. & Worker & 55 & 1.73 & 0.74 & & & & \\
\hline & 6. & Teacher & 53 & 1.87 & 0.85 & & & & \\
\hline & 7. & Doctor & 56 & 3.81 & 1.01 & & & & \\
\hline & 8. & Engineer & 51 & 1.98 & 0.75 & & & & \\
\hline & 9. & Academician & 56 & 1.88 & 0.82 & & & & \\
\hline & 10. & Tradesmen & 54 & 1.88 & 0.88 & & & & \\
\hline \multirow{10}{*}{$\begin{array}{l}\text { Price } \\
\text { consciousness }\end{array}$} & 1. & Officer & 56 & 3.44 & 1.34 & \multirow{10}{*}{21.39} & \multirow{10}{*}{$<0.01$} & \multirow{10}{*}{0.25} & \\
\hline & 2. & Student & 94 & 2.27 & 0.99 & & & & \\
\hline & 3. & Housewife & 53 & 3.06 & 1.37 & & & & $4>2,4>3,4>5,4>6,4>10$ \\
\hline & 4. & Manager & 51 & 4.32 & 0.88 & & & & \\
\hline & 5. & Worker & 55 & 3.26 & 1.04 & & & & $9>2,9>6,9>10$ \\
\hline & 6. & Teacher & 53 & 2.23 & 1.15 & & & & $8>2,8>6,8>10$ \\
\hline & 7. & Doctor & 56 & 3.39 & 1.38 & & & & $1>2,1>6,1>10$ \\
\hline & 8. & Engineer & 51 & 3.54 & 1.50 & & & & $\begin{array}{l}7>2,7>6,7>10 \\
5>2\end{array}$ \\
\hline & 9 . & Academician & 56 & 3.90 & 1.15 & & & & \\
\hline & 10. & Tradesmen & 54 & 2.26 & 1.18 & & & & \\
\hline & 1. & Officer & 56 & 2.39 & 1.18 & & & & \\
\hline & 2. & Student & 94 & 3.44 & 1.00 & & & & \\
\hline & 3. & Housewife & 53 & 4.29 & 1.03 & & & & $3>1,3>2,3>4,3>6,3>7,3>8$ \\
\hline & 4. & Manager & 51 & 1.62 & 0.81 & & & & $3>9,3>10$ \\
\hline Solo promonoca & 5. & Worker & 55 & 4.22 & 0.72 & 5110 & $<001$ & 045 & $5>1,5>4,5>6,5>7,5>8,5>9$ \\
\hline Sale proneness & 6. & Teacher & 53 & 2.90 & 0.92 & 51.19 & $<0.01$ & 0.45 & $5>10$ \\
\hline & 7. & Doctor & 56 & 2.21 & 0.95 & & & & $2>1,2>4,2>7,2>8,2>9,2>10$ \\
\hline & 8. & Engineer & 51 & 2.08 & 1.20 & & & & $6>4,6>8,6>9,6>10$ \\
\hline & 9. & Academician & 56 & 1.79 & 1.11 & & & & \\
\hline & 10. & Tradesmen & 54 & 2.09 & 1.14 & & & & \\
\hline & 1. & Officer & 56 & 2.05 & 1.08 & & & & $8>1,8>2,8>3,8>4 ; 8>5,8>6$ \\
\hline & 2. & Student & 94 & 3.22 & 1.11 & & & & $8>8,8>9,8>10$ \\
\hline & 3. & Housewife & 53 & 1.63 & 0.73 & & & & \\
\hline & 4. & Manager & 51 & 3.27 & 1.14 & & & & $7>1,7>3,7>5,7>6,7>8,7>9$ \\
\hline Price-quality & 5. & Worker & 55 & 1.87 & 0.92 & 3744 & $<0 \Omega 1$ & 037 & $7>10$ \\
\hline relationship & 6. & Teacher & 53 & 2.73 & 1.24 & 31.44 & $<0.01$ & $0.3 /$ & \\
\hline & 7. & Doctor & 56 & 3.56 & 1.00 & & & & $4>1,4>3,4>5,4>8,4>9,4>10$ \\
\hline & 8. & Engineer & 51 & 4.19 & 1.18 & & & & \\
\hline & 9. & Academician & 56 & 2.35 & 1.01 & & & & $6>3,6>5,6>8,6>10$ \\
\hline & 10. & Tradesmen & 54 & 1.78 & 0.92 & & & & $9>3,9>5,9>8,9>10$ \\
\hline & 1. & Officer & 56 & 2.24 & 1.06 & & & & \\
\hline & 2. & Student & 94 & 3.71 & 0.94 & & & & \\
\hline & 3. & Housewife & 53 & 3.07 & 1.14 & & & & $9>1,9>3,9>4 ; 9>5,9>6,9>7$ \\
\hline & 4. & Manager & 51 & 1.69 & 1.04 & & & & $9>8,9>10$ \\
\hline Value & 5. & Worker & 55 & 2.03 & 0.93 & 3671 & $<001$ & 037 & \\
\hline consciousness & 6. & Teacher & 53 & 3.20 & 1.20 & 36.71 & $<0.01$ & 0.37 & $2>1,2>4 ; 2>5,2>7,2>8,2>10$ \\
\hline & 7. & Doctor & 56 & 2.44 & 0.89 & & & & \\
\hline & 8. & Engineer & 51 & 2.29 & 1.18 & & & & $3>1,3>4 ; 3>5,3>8,3>10$ \\
\hline & 9. & Academician & 56 & 4.14 & 0.88 & & & & \\
\hline & 10. & Tradesmen & 54 & 2.17 & 0.97 & & & & \\
\hline
\end{tabular}


When the Table is examined, a significant difference was found in price mavenism, prestige sensitivity, sale proneness, price-quality relationship and value consciousness score averages of the participants in terms of their occupation $(p<0.05)$. The variable of occupation has a broad effect on price perception factors. Officer, student, housewife, teacher and engineer participants were found to have the highest price mavenism score averages, while manager, worker, doctor, academician and tradesmen participants were found to have the lowest price mavenism score averages. Student, manager and doctor participants were found to have the highest prestige sensitivity score averages, while officer, housewife and worker participants were found to have the lowest prestige sensitivity score averages.

Officer, manager, worker, doctor, engineer and academician participants were found to have the highest price consciousness score averages, while student, teacher and tradesman participants were found to have the lowest price consciousness score averages. Student, housewife, worker and teacher participants were found to have the highest sale proneness score averages, while manager, engineer, academician tradesmen participants were found to have the lowest sale proneness score averages.

Manager, teacher, doctor, engineer and academician participants were found to have the highest price-quality relationship score averages, while housewife, worker, engineer and tradesman participants were found to have the lowest price-quality relationship score averages. Student, housewife and academician participants were found to have the highest value consciousness score averages, while officer, manager, worker, engineer and tradesman participants were found to have the lowest value consciousness score averages.

Table 12 shows acceptance/rejection table of hypotheses.

Table 12: Acceptance/Rejection Table of Hypotheses

\begin{tabular}{|c|c|}
\hline Hypothesis & $\begin{array}{l}\text { Acceptance/Rejection } \\
\text { Table }\end{array}$ \\
\hline H1. There is a significant difference between consumers' occupations and their prices perceptions. & It was not rejected. \\
\hline $\begin{array}{l}\text { H1a. There is a significant difference between consumers' occupations and value consciousness, which } \\
\text { is one of the dimensions of price perception. }\end{array}$ & It was not rejected. \\
\hline $\begin{array}{l}\text { H1b. There is a significant difference between consumers' occupations and price consciousness, which } \\
\text { is one of the dimensions of price perception. }\end{array}$ & It was not rejected. \\
\hline $\begin{array}{l}\text { H1c. There is a significant difference between consumers' occupations and sale proneness, which is } \\
\text { one of the dimensions of price perception. }\end{array}$ & It was not rejected. \\
\hline $\begin{array}{l}\text { H1d. There is a significant difference between consumers' occupations and price mavenism, which is } \\
\text { one of the dimensions of price perception. }\end{array}$ & It was not rejected. \\
\hline $\begin{array}{l}\text { H1e. There is a significant difference between consumers' occupations and price-quality relationship, } \\
\text { which is one of the dimensions of price perception. }\end{array}$ & It was not rejected. \\
\hline $\begin{array}{l}\text { H1f. There is a significant difference between consumers' occupations and prestige sensitivity, which } \\
\text { is one of the dimensions of price perception. }\end{array}$ & It was not rejected. \\
\hline $\begin{array}{l}\text { H2. There is a significant difference between consumers' demographic characteristics and their prices } \\
\text { perceptions. }\end{array}$ & It was not rejected. \\
\hline H2a. There is a significant difference between consumers' genders and their prices perceptions. & It was not rejected. \\
\hline H2b. There is a significant difference between consumers' ages and their prices perceptions. & It was not rejected. \\
\hline $\begin{array}{l}\text { H2c. There is a significant difference between consumers' education levels and their prices } \\
\text { perceptions. }\end{array}$ & It was not rejected. \\
\hline $\mathrm{H} 2 \mathrm{~d}$. There is a significant difference between & It was not rejected. \\
\hline
\end{tabular}




\section{CONCLUSION}

The aim of the present study is to examine the relationship between consumers' price perceptions and their gender, age, educational status, income level and occupations. With this purpose, 579 participants were reached in Turkey. It is thought that finding out the price perception dimensions of the consumers in Turkey and the factors related with these dimensions will shed a light on the pricing policies of companies in this market. In addition, the study was conducted in the current economic process of Turkey. Thus, it can be said that this study is a current study which reflects the dimensions of consumers' price perceptions and the relationship of these with their occupation and that it is an important study in this sense.

According to the results obtained, female participants were found to have higher sale proneness than male participants. Bozbay and Akturan (2017) and Topuz and Çambaşı (2014) found similar results in literature. According to the results of the relationship between price perception and consumers' age groups, price mavenism, sale proneness and value consciousness score averages of the participants in "18-25" age group were found to be higher than those of the participants in other age groups. It has been stated in literature that young consumers are consumers with value consciousness (Zhou and Nakamoto, 2001: 161).

According to the results of the study, it was found that participants with moderate and low level of income had higher price mavenism and sale proneness score averages. Participants with high income were found to have higher prestige sensitivity, price consciousness and price-quality relationship score averages than the other income groups. High value consciousness averages of consumers with the lowest level of income are a result reported in literature (Steenhuis et al., 2011: 2220). It can be seen that these results are in parallel with the results in literature.

Consumers' income levels influence their buying behaviors (Ohen et al., 2014: 55). At the same time, income level of consumers is an important factor influencing their price perceptions. For example, consumers with high level of income have less price conscious behaviors towards hedonic products when compared with functional products (Wakefield and Inman, 2003: 199). It can be seen that consumers' price sensitivity increases as their level of income decreases (Andreyeva et al., 2010: 218). When studies conducted in Turkey are examined, it can be seen that regardless of the level of income, consumers paid high importance to the price of holiday in tourism sector. Akman (2004: 145) stated that consumers had increased tendency to compare prices as their socio-economic status decreased. Fettahlıoğlu et al. (2019: 5936) stated that consumers with an income of $8001 \mathrm{Tl}$ and higher bought organic products due to prestige sensitivity and hedonic effects.

The relationship between income levels and price perceptions of consumers are in parallel with their level of education. In general, participants with undergraduate, master and doctorate degrees have the highest prestige sensitivity, price consciousness and price-quality relationship score averages. In addition, it was found that participants with associate, undergraduate, master and doctorate degrees had higher score averages than participants with primary education degree.

It is thought that participants' occupations reflect income and education levels in general. According to the results of the study, doctors and managers were found to have the highest score averages in prestige sensitivity. When prices are perceived positively, they are seen as a symbol of quality, prestige or status (Lichtenstein et al., 1990: 56). Doctors and managers have high levels of income and education. For this reason, it is thought that the statuses of doctors and managers have an influence on their price perception and as a result they have prestige sensitivity. It has also been found that manager consumers are consumers with high price consciousness.

In price-quality relationship, one of the price perception dimensions, engineers followed by doctors were found to have the highest score averages. Consumers use price-quality relationship when they do not have enough time to evaluate other alternative products or when they do not have enough information to evaluate the products (Kinney et al., 2012: 65). For this reason, since consumers who 
have a busy work life such as engineers and doctors do not have too much time to compare sales or prices and since they have enough level of income, it is thought that they evaluate products with their prices.

According to the results of the study, housewives, workers and students have high sale proneness. Some consumers evaluate their income as scarce source and for this reason, price is considered as a renunciation (Lichtenstein et al., 1993: 234). It is thought that housewives, students and workers, who are among occupations with low level of income, have high sale proneness due to this situation. It can be said that these results are similar to results conducted previously (Fettahlioğlu et al., 2019; Topuz and Çambaş1, 2014).

The results of the study showed that teacher and academician consumers had high value consciousness. For this reason, these consumers consist of consumers who evaluate the price they pay for the products they buy as loss or gain according to the quality of the product and who have high value consciousness. It can be thought that a majority of these consumers try to earn their living without making too much expense with a search of both quality and value since they are middle class with a fixed income. Officer consumers are found to have the highest average in the dimension of price mavenism. These consumers are at the same time consumers with high price consciousness. It can be said that these consumers make researches in the period of time that they have left from their work life which is not very busy and that they like sharing the results of these researches with their friends and that they focus on low price products since they have moderate or low levels of income. It was also found that consumers who were tradesmen had price consciousness. It can be thought that these consumers want to have a profitable shopping by focusing on low price products in their personal shopping since they buy and sell products in their business life and since they manage this process.

\section{Implications}

In the light of the results obtained from the study, the following recommendations were made for practitioners and companies:

- In parallel with the relationship between consumers' price perceptions and their occupation, companies can develop their pricing policies in their market according to occupation groups. It is thought that this situation will contribute to an easier and faster access to target group.

- Turkey is a developing and crowded country with its approximately 81 million population. For this reason, it is thought that the companies which operate in Turkish market or which want to operate in this market can make use of the results of this study in their marketing segments or pricing policies. For example, special informing websites can be designed to contribute to officer consumers, who have price mavenism, in sharing information about prices of products, advertisement catalogues can be used and free memberships can be given to institutions these consumers work in.

- Occupations are an important variable in marketing segments. This study shows that consumers' occupations can be taken into consideration in marketing segments for price perception. For example, companies which have managers and doctors as target groups can conduct promotional activities which emphasize prestige.

- It is thought that it will be useful for companies to conduct pricing policies and marketing segmentation by taking into consideration the relationship between consumers' demographic characteristics and price perception dimensions. For example, companies which appeal to young consumers can develop strategies which will enable getting the highest value for the price paid for their products.

- It is thought that it will be useful for companies which choose consumers with high value consciousness, price consciousness and price sensitivity, which constitute the negative role of price, to conduct promotional activities which emphasize the positive roles of price perception (quality and prestige). 
In terms of sample, the fact that the study was conducted on Ankara, Samsun and İstanbul and that it constituted 579 consumers are the limitations of the study. At the same time, use of easy sampling method due to time and financial constraints and the survey environment not being comprehensive are among other limitations of the study. For this reason, conducting the study in different cities, on different sectors and on wider occupation groups can be useful in terms of getting more comprehensive results. In addition, it is thought that it will be effective to examine the relationship between price perception and different variables such as conspicuous consumption, sense of self, online consumption, advertisement or consumer innovation.

\section{REFERENCES}

Ağaç, S., Sevinir, S. D. and Yılmaz, T. (2018). Online giyim alışverişinde tüketicilerin karşılaştıkları sorunların cinsiyet değişkenine göre incelenmesi. Karadeniz Teknik Üniversitesi Sosyal $\begin{array}{lllll}\text { Bilimler Enstitüsü } \quad \text { Sosyal Bilimler } & \text { 5ergisi, }\end{array}$ https://dergipark.org.tr/en/pub/sbed/issue/38132/340011

Akman, S. U. (2004). Tüketicilerin fiyat bilinci üzerinde etkili olan faktörlere ilişkin bir inceleme. Maliye Araştırma Merkezi Konferanslart, 46(1), 129-147. https://dergipark.org.tr/en/downloa $\mathrm{d} /$ article-file/7259

Andreyeva, T., Long, M. W. and Brownell, K. D. (2010). The impact of food prices on consumption: A systematic review of research on the price elasticity of demand for food. Am J Public Health, 100(2), 216-222. https://ajph.aphapublications.org/doi/full/10.2105/AJPH.2008.151415

Armağan, E. and Gürsoy, Ö. (2011). Satın alma kararlarında tüketici etnosentrizmi ve menşe ülke etkisinin cetscale ölçeği ile değerlendirilmesi. Organizasyon ve Yönetim Bilimleri Dergisi, 3(2), 67-77. https://dergipark.org.tr/en/download/article-file/150971

Arnold, M. J. and Reynolds, K. E. (2003). Hedonic shopping motivations. Journal of Retailing. 29(2), 77-95. https://doi.org/10.1016/S0022-4359(03)00007-1

Arslan, İ. K. (2003). Otomobil alımında tüketici davranışlarını etkileyen faktörler. İstanbul Ticaret Üniversitesi Dergisi, 2(3), 83-103. http://acikerisim.ticaret.edu.tr/xmlui/bitstream/handle/ 11467/209/M00042.pdf?sequence

Atılgan, K. Ö. and Koç, O. (2020). İndirim düzeyleri ve sosyal sınıflar açısından tüketici fiyat algısındaki farkl11ıkların incelenmesi. Mehmet Akif Ersoy Üniversitesi İktisadi ve İdari Bilimler Fakültesi Dergisi, 7(Özel Say1), 1075-1103. https://doi.org/10.30798/makuiibf.822900

Aydın, F. and Yıldız, Ş. (2011). Sivas ilinde ekmek tüketim alışkanlıkları ve tüketici dinamiklerinin belirlenmesi. Atatürk Üniversitesi Ziraat Fakültesi Dergisi, 42 (2), 165-180. https://dergipark.org.tr/en/pub/ataunizfd/issue/3015/41861

Bei, L. T. and Chiao, Y. C. (2001). An integrated model for the effects of perceived product, perceived service quality, and perceived price fairness on consumer satisfaction and loyalty. Journal of Consumer Satisfaction, Dissatisfaction and Complaining Behavior, 14, 125-140.

Bei, L. T. and Chiao, Y. C. (2006). The determinants of customer loyalty: An analysis of intangible factors in three service industries. International Journal of CommerceandManagement, 16(3/4), 162-177. https://doi.org/10.1108/10569210680000215

Bentler, P. M. (1990). Comparative fit indexes in structural models. Psychological Bulletin, 107(2), 238-246. https://doi.org/10.1037/0033-2909.107.2.238

Bentler, P. M. and Bonett, D. G. (1980). Significance tests and goodness of fit in the analysis of covariance structures. Psychological Bulletin, 88(3), 588-606. https://doi.org/10.1037/00332909.88.3.588

Bozbay, Z. and Akturan, U. (2017). Cinsiyet ve alışveriş davranışının fiyat algılamaları ile ilişkisinin saptanması: Y kuşağı üzerine bir araştırma. Finans Politik and Ekonomik Yorumlar, 54(629), 87-101. https://dergipark.org.tr/en/pub/fpeyd/issue/48014/607274

Browne, M. W. and Cudeck, R. (1993). Alternative ways of assessing model fit. K. A. Bollen and J. S. Long (Ed.) içinde Testing structural equation models (s. 136-162). Sage Focus Editions. 
Brucks, M., Zeithaml, V. and Naylor, G., (2000). Price and brand name as indicators of quality dimensions for consumer durables. Journal of the Academy of Marketing Science, 28(3), 359374. https://doi.org/10.1177/0092070300283005

Byun, S. E. and Sternquist, B. (2010). Reconceptualization of price mavenism: Do chinese consumers get a glow when they know?. Asia Journal of Marketing and Logistics, 22(3), 279-293. https://doi.org/10.1108/13555851011062232

Carmines, E. G. McIver (1981). Analyzing models with unobserved variables: Analysis of covariance structures. Sage.

Casidy, R. (2012). Discovering consumer personality clusters in prestige sensitivity and fashion consciousness context. Journal of International Consumer Marketing, 24(4), 291-299. https://doi.org/10.1080/08961530.2012.728506

Chang, S. S., Chang, C. C. and Su, W.G. (2015). Quality or sacrifice? The influence of decision task and product characteristics on the dual role of price. Psychological Reports, 117(1), 72-88. https://doi.org/10.2466/01.PR0.117c14z3

Cohen, J. (1988). Statistical Power Analysis For The Behavioral Sciences. Erlbaum.

Çabuk, P, Nakıboğlu, A. and Keleş, C. (2008). Tüketicilerin yeşil ürün satın alma davranışlarının sosyo demografik değişkenler açısından incelenmesi. Çukurova Üniversitesi Sosyal Bilimler Enstitüsü Dergisi, 17 (1), 85-102. https://dergipark.org.tr/en/pub/cusosbil/issue/4378/60011

Çabuk, Y., Karayılmazlar, S. and Türedi, H. (2012). Mobilya tercihinde tüketici davranışlarının demografik faktörler bakımından incelenmesi (Zonguldak ili örneği). Bartın Orman Fakültesi Dergisi, 14 (21), 1-10. https://dergipark.org.tr/en/pub/barofd/issue/3392/46726

Çakıcı, C. (1999), Turist satın alma davranışlarının otel işletmeciliği açısından incelenmesi. Pazarlama Dünyası Dergisi, 78, 31-37.

Dickson, P. R. and Sawyer, A. G. (1990). The price knowledge and search of supermarket shoppers. The Journal of Marketing, 54(3), 42-53. https://doi.org/10.1177/002224299005400304

Dodds, W. B., K. B. Monroe and D. Grewal (1991). Effects of price, brand, and store information on buyers' product evaluations. Journal of Marketing Research, 28(3), 307-319. https://doi.org/10.1177/002224379102800305

Durmaz, Y., Bahar, R. and Kurtlar, M. (2011). Kişisel faktörlerin tüketici satın alma davranışlarına etkisi üzerine bir araştırma. Akademik Yaklaşımlar Dergisi, 2 (1), 114-133. https://dergipark.org.tr/en/pub/ayd/issue/3325/46151

Ene, S. and Özkaya, B. (2013). A study regarding the attitudes that are effective on the price perception of consumers that shop from the retail stores. Mediterranean Journal of Social Sciences, 4(11), 451-462. https://doi.org/10.5901/mjss.2013.v4n11p451

Fettahlıoğlu, S., Atılgan, C. B. and Çildir, Ç. (2019). Organik ürünlere karşı tüketicilerin fiyat duyarlılığ 1 ve demografik faktörler açısından incelenmesi. International Social Sciences Studies Journal, 5(47), 5930-5939. http://dx.doi.org/10.26449/sssj.1562

Field, A. (2013). Discovering statistics using IBM SPSS statistics. Sage.

Folkes, V. and Wheat, R. D. (1995). Consumers' price perceptions of promoted products. Journal of Retailing, 71(3), 317-328. https://doi.org/10.1016/0022-4359(95)90028-4

Geçti, F. and Zengin, H. (2012). Fiyat algılamasının boyutları arasındaki ilişkilerin incelenmesi: Ak1llı telefon tüketicilerine yönelik bir araştırma. Sakarya İktisat Dergisi, 1(4), 28-56. https://dergipark.org.tr/en/pub/sid/issue/30090/324701

Gürbüz, A. and Doğan, M. (2013). Tüketicilerin markaya duyduğu güven ve marka bağl1lığı ilişkisi. Uluslararası Yönetim İktisat ve İsletme Dergisi, 9 (19), 239-258. https://doi.org/10.11122/ijmeb.2013.9.19.345

Hartono, B. D., Khambali, A. and Nugroho, R. E. (2018). Customer loyaty in chemical cosmetics: Analysis of product differentiation, service differentiation, and price perception. Asian Journal of Management Sciences and Education, 7(4), 94-108. https://core.ac.uk/download/pdf/291483803.pdf 
Haşıloğlu, S., Baran, T. and Aydın, O. (2015). Pazarlama araştırmalarındaki potansiyel problemlere yönelik bir araştırma: Kolayda örnekleme ve sıklık ifadeli ölçek maddeleri. Pamukkale Işletme ve Bilişim Yönetimi Dergisi, (1), 19-28. https://doi.org/10.5505/pibyd.2015.47966

Jacoby, J. and Olson, J. C. (1977). Consumer Response to Price: An Attitudinal, Information Processing Perspective. Y. Wind, and M. Greenberg (Ed.) Moving Ahead with Attitude Research içinde (s. 73-86), American Marketing Association.

Jeong, J. (2004). Analysis of the factors and the roles of hrd in organizational learning styles as 1dentified by key informants at selected corporations in the republic of Korea. (Yayımlanmamış Doktora Tezi). Texas AandM University. Amerika.

Jin, B. and Sternquist, B. (2003). The influence of retail environment on price perceptions-an exploratory study of Us and Korean students. International Marketing Review, 20(6), 643-660. https://doi.org/10.1108/02651330310505231

Joreskog, K. G. and Sorbom, D. (1984). Lisrel Vl: analysis of linear structural relationships by the method of maximum likelihood: User's guide. Scientific Software.

Karabulut, M., (1981). Tüketici davranışı pazarlama yeniliklerinin kabulu ve yayılışı. Fatih Yayınevi.

Kavak, B. and Aksöz, E. O. (2003). Davranışsal ve demografik değişkenlerin seyahat acentası müşterilerinin bölümlendirilmesindeki etkililikleri üzerine bir araştırma. Hacettepe Üniversitesi Iktisadi ve İdari Bilimler Fakültesi Dergisi, 21(1), 229-242. https://dergipark.org.tr/en/pub/huniibf/issue/7882/103580

Kinney, M. K., Ridgway, N. M. and Monroe, K. M. (2012). The role of price in the behavior and purchase decisions of compulsive buyers. Journal of Retailing, 88, 63-71. https://doi.org/10.1016/j.jretai.2011.02.004

Kline, R. B. (2011). Convergence of structural equation modeling and multilevel modeling. M. Williams and W. P. Vogt (Ed.) Handbook of methodological innovation içinde (s. 562-589). Sage.

Kurtuluş, K. and Okumuş, A. (2006). Fiyat algılamasının boyutları arasındaki ilişkilerin yapısal $\begin{array}{lllll}\text { eşitlik modellemesi ile incelenmesi. Yönetim, } & \text { 17(53), }\end{array}$ https://dergipark.org.tr/en/pub/sid/issue/30090/324701

Küçükergin, K. G. and Dedeoğlu, B. B. (2014). Fast food restoranlarında fiziksel çevre, fiyat algısı ve tekrar satın alma eğilimi arasındaki ilişkisi. Uluslararası Alanya İşletme Fakültesi Dergisi, 6(1),101-108. https://dergipark.org.tr/en/download/article-file/201777

Leblebicioğlu, B. and Bilgen, İ. (2019). Tüketicilerin fiyat algılamalarının indirim marketlerinden satın alma niyetleri üzerindeki etkisi. İstanbul Gelişim Üniversitesi Sosyal Bilimler Dergisi, 6, 141-154. https://doi.org/10.17336/igusbd.609121

Lichtenstein, D. R., Ridgway, N. M. and Netemeyer, R. G. (1993). Price perceptions and consumer shopping behavior: A field study. Journal of Marketing Research, 30(2), 234-245. https://doi.org/10.1177/002224379303000208

Lichtenstein, D. R.; Netemeyer, R. G. and Burton, S. (1990). Distinguishing coupon proneness from value consciousness: An acquisition-transaction utility theory perspective. Journal of Marketing, 54(3), 54-67. https://doi.org/10.1177/002224299005400305

Marsh, H. W. and Hocevar, D. (1985). Application of confirmatory factor analysis to the study of self-concept: First-and higher order factor models and their invariance across groups. Psychological Bulletin, 97(3), 562-582. https://doi.org/10.1037/0033-2909.97.3.562

McDonald, R. P. and Marsh, H. W. (1990). Choosing a multivariate model: Noncentrality and goodness of fit. Psychological Bulletin, 107(2), 247-255. https://psycnet.apa.org/doi/10.1037/0033-2909.107.2.247

McGowan, K. M. and Sternquist, B. J. (1998). Dimensions of price as a marketing universal: A comparison of Japanise and U.S. consumers. Journal of International Marketing, 6(4), 49-65. https://doi.org/10.1177/1069031X9800600408 
Meng, J. and Nasco, S.A. (2009). Cross-cultural equivalence of price perceptions across American, Chinese, and Japanese consumers. Journal of Product and Brand Management, 18(7), 506-516. https://doi.org/10.1108/10610420910998235

Meng, J. G. (2011). Understanding cultural influence on price perception: Empirical insights from a sem application. Journal of Product and Brand Management, 20(7), 526-540. https://doi.org/10.1108/10610421111181831

Moore, M. and Carpenter, J. (2006). The effect of price as a marketplace cue on retail patronage. Journal of Product and Brand Management, 15(4), 265-271. https://doi.org/10.1108/10610420610679647

Moore, M., McGowan K., K. and Fairhurst, A. (2003). Cross-cultural equivalence of price perceptions between US and Polish consumers. International Journal of Retail and Distribution Management, 31(5), 268-279. https://doi.org/10.1108/09590550310472433

Munnukka, J. (2008). Customers' purchase intentions as a reflection of price perception. Journal of Product and Brand Management, 17(3), 188-196. https://doi.org/10.1108/10610420810875106

Musellim, F. (2021). Kişilik tipleri ve fiyat algısl: Antalya destinasyonu ziyaretçileri üzerine bir araştırma (Yayınlanmamış Yüksek Lisans Tezi). Karabük Üniversitesi Lisanüstü Eğitim Enstitüsü, Karabük.

Mutsikiwa M. and Basera C. H. (2012), The influence of socio-cultural variables on consumers' perception of halal food products: A case of Masvingo Urban, Zimbabwe. International Journal of Business and Management, 7(20), 112-119. https://pdfs.semanticscholar.org/18a9/730c9d9562785dacb763d79571eac09e1cd0.pdf

Ohen, S., Umeze, G. and Inyang, E. (2014). Consumer purchasing behaviour for fruits and vegetables among civil servants in Essien Udim Local Government Area, Akwalbom State, Nigeria. Food Science and Quality Management, 55-64. https://citeseerx.ist.psu.edu/viewdoc/download?doi=10.1.1.846.6822\&rep=rep1\&type=pdf

Olson, J. C. (1977). Price as an informational cue: Effects on product evaluations. A. G. Woodside, J. N. Sheth and P. D. Bennett (Ed.). Consumer and industrial buying behavior içinde (s. 267286). North Holland.

Orel, Y. (2004). Market markaları ve üretici markalarına yönelik tüketici algılamaları. Çukurova Üniversitesi Sosyal Bilimler Enstitüsü Dergisi, 13(2), 157-174. https://dergipark.org.tr/en/pub/cusosbil/issue/4370/59777

Özdamar, K. (2004). Paket programlar ile istatistiksel veri analizi (çok değişkenli analizler). Kaan Kitabevi.

Özdemir, N. (2018). Yeni Türk alfabesi'nin kabulü sonrasında Türkiye'de gazete promosyonları. Cumhuriyet Tarihi Araştırmalarl Dergisi, 14(28), 135-162. http://www.ctad.hacettepe.edu.tr/14_28/05_nuray_ozdemir.pdf

Peter, P. J. and Olson, J. C. (2010). Consumer behavior and marketing strategy. McGraw-Hill.

Ramya, N. and Mohamed Ali, S. A. (2016). Factors affecting consumer buying behavior. International Journal of Applied Research, 2(10), 76-80.

Rao, A. R. and Monroe, K. B. (1988). The moderating effect of prior knowledge on cue utilization in product evalutions. Journal of Consume Research, 15, 253-264. https://doi.org/10.1086/209162

Rao, A. R. and Monroe, K. B. (1989). The effect of price, brand name, and store name on buyers' perceptions of product quality: An integrative review. Journal of Marketing Research, 26(3), 351-357. https://doi.org/10.1177\%2F002224378902600309

Saba, A. and Messina, F. (2003). Attitudes towards organic foods and risk/benefit perception associated with pesticides. Food Quality and Preference, 14, 637-645. https://doi.org/10.1016/S0950-3293(02)00188-X

Sharma, P. (2011). Country of origin effects in developed and emerging markets: Exploring the contrasting roles of materialism and value consciousness. Journal of International Business Studies, 42(2), 285-306. https://doi.org/10.1057/jibs.2010.16

Solomon, M. R. (1994). Consumer behavior: Buying, having and being. Paramount Publishing. 
Steenhuis, I. H. M., Waterlander, W. E. and Mul, A. (2011). Consumer food choices: The role of price and pricing strategies. Public Health Nutrition, 14(12), 2220-2226. https://doi.org/10.1017/S1368980011001637

Sternquist, B., Byun, S. E. and Jin, B. (2004). The dimensionality of price perceptions: a crosscultural comparison of asian consumers. The International Review of Retail, Distribution and Consumer Research, 14(1), 83-100. https://doi.org/10.1080/0959396032000154310

Tanaka, J. S. and Huba, G. J. (1985). A fit index for covariance structure models under arbitrary gls estimation. British Journal of Mathematical and Statistical Psychology, 38(2), 197-201. https://doi.org/10.1111/j.2044-8317.1985.tb00834.x

Tavşancıl, E. (2005). Tutumların Ölçülmesi ve SPSS ile Veri Analizi. Nobel Basımevi.

Topuz, Y. and Çambaşı, İ. (2014). Asgari ücretli tüketicilerin fiyat ve fiyat-kalite algısı: Cep telefonu ürünleri üzerine bir araştırma. Academic Review of Economics and Administrative Sciences, $7(1), 315-327$.

Ustaahmetoğlu, E. (2014). Fiyat promosyonlarının algılanan tasarrufa etkisi üzerine deneysel bir araştırma. Journal of Consumer and Consumption Research, 6(2) 1-23.

Ünsalan, A. G. M. and Bayraktar, A. (2017). Tüketici etnosentrizminin tüketici fiyat algısına etkisi, International Journal of Academic Value Studies, 3(9), 258-272.

Varki, S. and Colgate, M. (2001). The role of price perceptions in an integrated model of behavioral $\begin{array}{llll}\text { intentions. Journal of } & \text { 232-240. }\end{array}$ https://doi.org/10.1177/109467050133004

Wakefield, K.L. and J. Jeffrey Inman (2003). Situational price sensitivity: The role of consumption occasion, social context, and income. Journal of Retailing, 79(4), 199-212. https://doi.org/10.1016/j.jretai.2003.09.004

Watchravesringkan, K.T., Yan, R. N. and Yurchisin, J. (2008). Cross-cultural invariance of consumers' price perception Measures-Eastern Asian perspective. International Journal of $\begin{array}{llll}\text { Retail and } \quad \text { Distribution } & \text { Management, }\end{array}$ https://doi.org/10.1108/09590550810900982

Yağar, F. and Dökme, S. (2018). Niteliksel araştırmaların planlanması: Araştırma soruları, örneklem seçimi, geçerlik ve güvenirlik. Gazi Sağllk Bilimleri Dergisi, 3(3), 1-9. https://dergipark.org.tr/en/pub/gsbdergi/issue/39953/474327

Yan, J., Tian, K., Herav1, S. and Morgan, P. (2017). The vices and virtues of consumption choices: Price promotion and consumer decision making. Marketing Letters, 28(3), 461-475. https://doi.org/10.1007/s11002-017-9421-x

Yaraş, E. (2008). Tüketicilerin fiyat algılamalarına yönelik bir araştırma. Sosyal Ekonomik Araştırmalar Dergisi, 8(15), 281-300. https://dergipark.org.tr/en/pub/susead/issue/28424/ 302720

Yayl1, A. and Yayla, İ. (2012). Turistlerin her şey dahil sistemini tercih etme nedenleri. Işsletme Araştırmaları Dergisi, 4(1), 143-162.

Zeithaml, V. A. (1988). Consumer perceptions of price, quality, and value- a means-end model and $\begin{array}{llll}\text { snthesis of evidence. Journal of } & \text { 2-22. }\end{array}$ https://doi.org/10.1177/002224298805200302

Zhou, Z. and Nakamato, K. (2001). Price perceptions: A cross-national study between American and Chinese young consumers. Advances in Consumer Research, 28, 1061-168. https://www.acrwebsite.org/volumes/8462/volumes/v28/NA-28 